\title{
Prudent Investor Rule and Market Risk: An Empirical Analysis
}

\section{Citation}

Robert H. Sitkoff \& Max Schanzenbach, Prudent Investor Rule and Market Risk: An Empirical Analysis, (Harv. Pub. Law Working Paper No. 15-06, Nw. Pub. Law Res. Paper No. 15-16, John M. Olin Center for Law, Economics, and Business Discussion Paper No. 816, Mar. 20, 2015).

\section{Published Version}

http://www.law.harvard.edu/programs/olin_center/papers/pdf/Sitkoff_816.pdf

\section{Permanent link}

http://nrs.harvard.edu/urn-3:HUL.InstRepos:17367904

\section{Terms of Use}

This article was downloaded from Harvard University's DASH repository, and is made available under the terms and conditions applicable to Other Posted Material, as set forth at http:// nrs.harvard.edu/urn-3:HUL.InstRepos:dash.current.terms-of-use\#LAA

\section{Share Your Story}

The Harvard community has made this article openly available.

Please share how this access benefits you. Submit a story.

Accessibility 


\title{
HARVARD
}

JOHN M. OLIN CENTER FOR LAW, ECONOMICS, AND BUSINESS

\author{
THE PRUDENT INVESTOR RULE AND MARKET RISK: \\ AN EMPIRICAL ANALYSIS \\ Max M. Schanzenbach \\ Robert H. Sitkoff
}

Discussion Paper No. 816

$03 / 2015$

Harvard Law School

Cambridge, MA 02138

This paper can be downloaded without charge from:

The Harvard John M. Olin Discussion Paper Series:

http://www.law.harvard.edu/programs/olin_center/

The Social Science Research Network Electronic Paper Collection: http://ssrn.com/abstract=2583775 


\title{
The Prudent Investor Rule and Market Risk: An Empirical Analysis
}

\author{
Max M. Schanzenbach ${ }^{*}$ \\ Robert H. Sitkoff**
}

\begin{abstract}
The prudent investor rule, enacted in every state over the last 30 years, is the centerpiece of fiduciary investment law. Repudiating the prior law's emphasis on avoiding risk, the rule reorients fiduciary investment toward risk management in accordance with modern portfolio theory. The rule directs trustees to implement an overall investment strategy having risk and return objectives reasonably suited to the trust. Using data from reports of bank trust holdings and fiduciary income tax returns, we examine trustee management of market risk before and after the reform. First, we find that the reform increased stock holdings only among banks with average trust account sizes above the 25th percentile. This result is consistent with sensitivity in asset allocation to beneficiary risk tolerance as proxied by account size. Second, we find that, although stockholdings increased after the reform, trust corpus did not become more correlated with the market. We explain this result in part with evidence of increased portfolio rebalancing after the reform. We conclude that the rule's command to align market risk with beneficiary risk tolerance, and to manage market risk exposure on an ongoing basis, has largely been followed.
\end{abstract}

\footnotetext{
* Professor of Law, Northwestern University, m-schanzenbach@law.harvard.edu.
}

** John L. Gray Professor of Law, Harvard University, rsitkoff@law.harvard.edu.

The authors thank David Abrams, John Campbell, David Coffaro, Allen Ferrell, Jesse Fried, John Goldberg, Marcel Kahan, Yotam Kaplan, Louis Kaplow, Jonathan Klick, Howell Jackson, John Langbein, A. Mitchell Polinsky, Steven Shavell, Henry Smith, Kathy Spier, Stewart Sterk, Lawrence Waggoner, and workshop participants at the annual meeting of the American Law and Economics Association, the Conference on Empirical Legal Studies, Columbia University, Harvard University, Northwestern University, and Stanford University. The authors also thank Terri Saint-Amour and Sandra Hough for excellent research assistance. Sitkoff thanks the Harvard Law School Summer Research Program for financial support. In accordance with Harvard Law School policy on conflicts of interest, Sitkoff discloses certain outside activities, one or more of which may relate to the subject matter of this article, at https://helios.law.harvard.edu/public/ConflictOfInterestReport.aspx?id=10813. 


\section{Introduction}

"October. This is one of the peculiarly dangerous months to speculate in stocks in. The others are July, January, September, April, November, May, March, June, December, August, and February" (Twain 1899, p. 123). The long tradition of equating stock investment with speculation deeply influenced the law of trust investment, which until recently discouraged investment in stock as "speculative.” By focusing categorically on risk avoidance, traditional law did not account for the difference between idiosyncratic risk and market risk, the relationship between risk and return, or beneficiary risk tolerance. Worse still, courts considered the riskiness of each investment in isolation rather than in light of overall portfolio risk.

Twentieth century advances in economics and finance, however, led to extensive reform to the law of trust investment. The centerpiece of this reform is the prudent investor rule, which reorients fiduciary investment from risk avoidance to risk management in accordance with modern portfolio theory. Because the rule has been adopted in every state, because it applies to the entire field of fiduciary investing, including pension funds and charitable endowments, and because it has been adopted across the British Commonwealth, the rule governs the investment of many trillions of dollars in assets.

As canonically stated by the Restatement (Third) of Trusts $\left(1992^{1}\right)$ and the Uniform Prudent Investor Act (1994) (hereafter, UPIA), the prudent investor rule requires a trustee to manage a trust portfolio with "an overall investment strategy having risk and return objectives reasonably suited to the trust" and to "diversify the investments of the trust" (UPIA, sec. 2[b], 3; see also Restatement [Third], sec. 90[a]-[b]). Upon assuming office, a trustee has a "reasonable time ... to make and implement" an investment program that complies with the rule (UPIA, sec. 4; Restatement [Third], sec. 92). Thereafter, compliance with the rule is a "continuing responsibility" (UPIA, sec. 2, comment). The trustee is under an "ongoing duty to monitor investments and to make portfolio adjustments if and as appropriate" (Restatement [Third], sec. 90, comment e[1]). Accordingly, under the rule a trustee must minimize idiosyncratic risk, align market risk with beneficiary risk tolerance, and manage market risk exposure on an ongoing basis. The rule thus reoriented trust investment law from categorical risk avoidance to more nuanced risk management.

Incorporating modern portfolio theory into the law of fiduciary investment should provoke little controversy. Whether fiduciaries have applied the law properly in practice, however, has yet to be studied. The importance of this question is highlighted by the fact that, since adoption of the rule, stockholdings in personal trusts have increased substantially at the expense of government bonds, in part in response to the rule (Schanzenbach and Sitkoff 2007). Against this backdrop of increased exposure to market risk since adoption of the rule, we examine how the rule has affected management of market risk by trustees. It bears repeating that the rule "does not call for avoidance of risk by trustees," but rather for "prudent management of risk" (Restatement [Third], sec. 90, comment e[1]).

Our analysis, which relies primarily on data from bank trust holdings, proceeds in two steps. First, we examine sensitivity to beneficiary risk tolerance in trust asset allocation. The heart of the prudent investor rule is the command to trustees to implement "an overall invest-

\footnotetext{
${ }^{1}$ The 1992 Restatement provision on the prudent investor rule was superseded without material changes by Restatement (Third) of Trusts $\S 90$ (2007) (hereafter, Restatement [Third]).
} 
ment strategy having risk and return objectives reasonably suited to the trust” (UPIA, sec. 2[b]; see also Restatement [Third], sec. 90[a]). We use average trust account size as a proxy for beneficiary risk tolerance, reasoning that beneficiaries of larger trusts will tend to have more tolerance for risk than beneficiaries of smaller trusts. The data show that stock holdings and average trust account size have been strongly correlated across the entire period under study, both before and after the reform. Moreover, we find that adoption of the prudent investor rule primarily increased stockholdings by banks with trust account sizes in the 25th to 90th percentiles. Banks with small average account sizes did not increase their stockholdings after the reform, likely because their trust accounts should have been conservatively invested in all events and so were not constrained solely by prior law. In some specifications, banks with the largest average account sizes also appear less responsive to the reform, implying that the reform may have mattered less for the largest trusts.

Second, we assess ongoing management of market risk by examining the correlation between yearly changes in aggregate trust corpus and yearly changes in the S\&P 500. In the words of the Restatement, "risk management by a trustee requires that careful attention be given to the particular trust's ... tolerance for volatility" (Restatement [Third], sec. 90, comment e[1]). We find that, although stock holdings and so exposure to market risk increased after the prudent investor rule, trust corpus did not become more correlated with the S\&P 500. To the contrary, a $1 \%$ change in the S\&P 500 results in a $0.5 \%$ change in trust corpus for all years studied, before and after the rule. We explain this finding with evidence of more frequent portfolio rebalancing after the reform in accordance with the rule's imposition of a duty to make ongoing portfolio adjustments. Because we observe trust corpus only at year end, but rebalancing occurs from time to time across the year, an increase in rebalancing could mute what might otherwise have been an increased correlation with the S\&P 500. We also discuss the possibility that after the reform trustees might have invested in a broader range of stocks than those that comprise the S\&P 500 (e.g., mid- and small-cap issues or foreign stocks), which would reduce the correlation between trust corpus and the S\&P 500.

Our findings suggest that the centerpiece of the prudent investor rule, the direction to align market risk with beneficiary risk tolerance and to manage risk on an ongoing basis, has largely been followed. Our findings thus correct a misunderstanding in an ongoing policy debate about the law governing fiduciary investing. Some have suggested that in the years leading up to the financial crisis of 2008, the rule invited trustees imprudently to allow market risk to accumulate through excessive stockholdings (see, for example, Sterk 2010; Hofri-Winogradow 2014, 2015; see also Fishman 2014). On this assumption of failed risk management, some have urged that the prudent investor rule be replaced with safe harbors or lists of approved investments (Sterk 2010; Getzler 2009). This study challenges the empirical basis for those proposals.

The remainder of this paper is organized as follows. Section II motivates the empirical analysis by reviewing the economics and finance of trust investment. Section III describes our data. Section IV reports our analysis and results. Section V concludes. 


\section{Trust Investment Law, Economics, and Finance}

\section{A. Fiduciary Governance}

A trust is a legal arrangement in which a settlor transfers property to a trustee to hold and manage as a fiduciary for one or more beneficiaries. ${ }^{2}$ Managerial intermediation by way of trusteeship allows the settlor to postpone and delegate important decisions about investment and distribution of the trust property. Instead of imposing inflexible instructions in advance, the trustee may be empowered to make investment and distribution decisions in light of changing market conditions and the beneficiaries' evolving circumstances. However, a trust puts the beneficiaries at the peril of the familiar agency problem arising from an incomplete contract that separates beneficial ownership from control; the worry is mismanagement or misappropriation by the trustee (Sitkoff 2004; Langbein 1995). The primary legal mechanism for suppressing agency costs is fiduciary obligation, a plastic concept that allows a court to complete the parties' contract ex post and impose liability on the fiduciary for conduct inconsistent with what the parties would have agreed had they anticipated the circumstances (Cooter and Friedman 1991; Easterbrook and Fischel 1993; Sitkoff 2014a).

In the context of trust governance, fiduciary obligation induces the trustee to adhere to the terms of the trust and to act prudently and in the best interests of the beneficiaries on pain of damages and disgorgement remedies (Sitkoff 2013; Langbein 2004). Trustees are subject to primary fiduciary duties of loyalty and prudence. Trustees are also subject to a host of subsidiary duties that reflect judicial and legislative elaboration of the meaning of loyalty and prudence as applied to specific circumstances (examples include the duties to keep records, to earmark trust property, and to keep the beneficiaries informed of significant developments). A trustee's fiduciary duties in the investment function of trusteeship are specified by the law of trust investment.

\section{B. The Legal Lists and Prudent Man Rule}

The law of trust investment "got off to a bad start" (Langbein 1996, p. 643). After the South Sea Bubble burst in 1720, the English Court of Chancery settled upon a list of presumptively proper investments for trustees. The list was later codified, albeit in a somewhat broader form, by statutes in England and across the United States. Reflecting the salience of default risk after the South Sea Bubble, these legal lists required risk avoidance. They tended to favor government bonds and first mortgages and to exclude investments in equity (Langbein and Posner 1976). Structurally, the legal lists were in keeping with the legal technology of the era, in which agency problems, such as between a trustee and a beneficiary, were resolved by limiting the agent's powers (Langbein 1995; Sitkoff 2011). The problem with disempowerment, however, is that it also disables the agent from undertaking acts useful for the principal, defeating the purpose of the agency.

In the seminal case of Harvard College v. Amory (26 Mass. 446, 469 [1830]), the Massachusetts Supreme Judicial Court rejected the legal list and adopted the prudent man rule. The court held that a trustee must "observe how men of prudence, discretion and intelligence manage their own affairs, not in regard to speculation, but in regard to the permanent disposition of their funds, considering the probable income, as well as the probable safety of the capital to be

\footnotetext{
${ }^{2}$ A settlor may also declare a trust with himself as trustee, that is, the trustee need not be a third party (Dukeminier and Sitkoff [2013], pp. 407-08).
} 
invested.” In the mid 1900s, after the American Bankers Association sponsored a model statute codifying Amory, most states abrogated their legal lists in favor of the prudent man rule (Langbein and Posner 1976; Shattuck 1951).

Although the prudent man rule was phrased as a standard that called for case-by-case adjudication in light of all the circumstances, in application courts generalized rules from the specific facts of prior cases, giving rise to "specific subrules prescribing the types and characteristics of permissible investments for trustees" (Restatement [Third], part 6, ch. 17, intro. note; see also Gordon 1987). In this way, the risk-avoidance emphasis of the legal lists persisted. "Based on some degree of risk that was abstractly perceived as excessive, broad categories of investments and techniques often came to be classified as 'speculative' and thus as imprudent per se” (Restatement [Third], part 6, ch. 17, intro note). In the Restatement (Second) of Trusts (hereinafter, Restatement [Second]), which was published in 1959, the American Law Institute took the position that investing in "speculative" stock, meaning a company without "regular earnings and paying regular dividends which may reasonably be expected to continue," buying securities on margin, or buying discounted bonds was presumptively improper (Restatement [Second], sec. 227, comment m). By contrast, “[o]rdinarily it is proper for a trustee to invest in ... bonds of the United States or of the State or of municipalities, in first mortgages on land, or in corporate bonds” (Restatement [Second], sec. 227, comment f).

The preoccupation with proscribing speculation and avoiding default risk encouraged investment in government bonds, hence exposure to inflation risk, and it invited hindsight bias in adjudication in the form of "post hoc searches for evidence that investments were too risky" (Rachlinski 2000, pp. 79-81). ${ }^{3}$ The problem of hindsight bias was aggravated by the practice of reviewing each investment in isolation rather than in the context of the portfolio as a whole. If a risky investment failed to pay off, the trustee faced liability exposure even if the investment was sound in the context of the portfolio as a whole. The rule thus worked perversely against diversification.

\section{The Prudent Investor Rule}

\section{Codifying Portfolio Theory}

Drawing primarily on the teachings of modern portfolio theory, in the late 1970s scholars and sophisticated practitioners began calling for reform of the prudent man rule (see, for example, Langbein and Posner 1976, 1977; Longstreth 1986; Gordon 1987). The key insight from portfolio theory was to differentiate between market risk, which is inherent to participating in the market, and idiosyncratic risk, which is particular to a given investment. Generally speaking, to obtain a greater expected return, an investor must assume greater market risk. Market risk is thus compensated in that more exposure to market risk yields more expected return. Idiosyncratic risk, by contrast, is generally uncompensated, because such risk can be reduced or even eliminated by diversifying. It follows, therefore, that the prudence of a given investment must be considered in light of its contribution to the overall portfolio's expected risk

\footnotetext{
${ }^{3}$ An infamous example is In re Chamberlain's Estate (156 A. 42, 43 [1931]):

It was common knowledge, not only amongst bankers and trust companies, but the general public as well, that the stock market condition at the time of testator's death [in August 1929] was an unhealthy one, that values were very much inflated, and that a crash was almost sure to occur. In view of this fact, I think it was the duty of the executors to dispose of these stocks immediately upon their qualification as executors, and that the loss to the estate resulting from their failure to act should be taken into consideration now in awarding them compensation for their services.
} 
and return. Under the prudent man rule, however, courts evaluated the prudence of each investment in isolation, without regard to its place with the portfolio as a whole.

These criticisms led to a movement in the mid to late 1980s to revise the prudent man rule, refashioning it as a prudent investor rule that would reorient the law of fiduciary investment from investment-level risk avoidance to portfolio-level risk management consistent with modern portfolio theory. The aspiration of the reform movement was "to free trustees from the old preoccupation with avoiding speculation” (Langbein 1996, p. 650). Widespread enactment of the reform came after the American Law Institute endorsed the reform in a 1992 revision to the Restatement of Trusts and the Uniform Law Commission promulgated the UPIA in 1994. The Appendix Table dates the earliest enactment of the prudent investor rule in each state, by which we mean a codification of portfolio-as-a-whole risk management. ${ }^{4}$ Most of these enactments occurred in the 1990s. By 2006, every state had adopted the UPIA or a nonuniform statute to similar effect (see also Kiziah 2011).

The fiduciary investment reforms of the prudent investor rule are two, ${ }^{5}$ corresponding to the learning from portfolio theory about the distinction between market risk and idiosyncratic risk. First, “[a] trustee's investment and management decisions respecting individual assets must be evaluated not in isolation but in the context of the trust portfolio as a whole and as a part of an overall investment strategy having risk and return objectives reasonably suited to the trust” (UPIA, sec. 2; see also Restatement [Third], sec. 90[a]). Second, a trustee must "diversify the investments of the trust unless the trustee reasonably determines that, because of special circumstances, the purposes of the trust are better served without diversifying” (UPIA, sec. 3; see also Restatement [Third], sec. 90[b]).

Accordingly, the prudent investor rule requires a trustee not to avoid risk altogether but rather to evaluate the beneficiaries' risk tolerance and the purpose of the trust, choose a level of overall market risk and expected return that is commensurate with the beneficiaries' risk tolerance and the purpose of the trust, and avoid wasteful idiosyncratic risk. ${ }^{6}$ Upon assuming office, a trustee has a "reasonable time ... to make and implement" a compliant investment program (UPIA, sec. 4; Restatement [Third], sec. 92). ${ }^{7}$ What constitutes a reasonable time is context specific, depending on factors such as the liquidity of the trust assets and the tax and other transaction costs of reallocation.

Moreover, a trustee is under an "ongoing duty to monitor investments and to make portfolio adjustments if and as appropriate" (Restatement [Third], sec. 90, comment e[1]), for example, by rebalancing the portfolio in light of actual investment performance and changes in the beneficiaries' circumstances. The rule thus governs the trustee's "continuing responsibility for oversight of the suitability of investments already made" as well as "the trustee's decisions respecting new investments” (UPIA sec. 2, comment).

\footnotetext{
${ }^{4}$ Several states that had adopted such a statute prior to the UPIA later replaced those statutes with the UPIA.

${ }^{5} \mathrm{~A}$ third reform was reversing the nondelegation rule of prior law to enable a trustee who lacks expertise in portfolio management to delegate that function to a specialist (see Langbein [1996], pp. 650-54).

${ }^{6}$ Dukeminier and Sitkoff (2013, p. 635) survey examples of "special circumstances" that could justify not diversifying and so bearing idiosyncratic risk.

${ }^{7}$ Federal law requires national banks, “[u]pon acceptance of fiduciary account for which [the bank] has investment discretion, ... [to] conduct a prompt review of all assets of the account to evaluate whether they are appropriate for the account” (12 C.F.R. §9.6[b]).
} 
The difficulty in applying the prudent investor rule is that prudent management of market risk requires "quite subjective judgments that are essentially unavoidable in the process of asset management, addressing the appropriate degree of risk to be undertaken in pursuit of a higher or lower level of expected return from the trust portfolio" (Restatement [Third], sec. 90, comment e[1]). What makes this judgment subjective is that "tolerance for risk varies greatly with the financial and other circumstances of the investor, or in the case of a trust, with the purposes of the trust and the relevant circumstances of the beneficiaries. A trust whose main purpose is to support an elderly widow of modest means will have a lower risk tolerance than a trust to accumulate for a young scion of great wealth" (UPIA, sec. 2, comment). Because "no objective, general legal standard can be set for a degree of risk that is or is not prudent" (Restatement [Third] sec. 90, comment e[1]), there is typically a band of reasonable discretion in which more than one course of conduct would be prudent. The rule imposes liability for imprudent investment management, that is, for an investment program that falls outside of this band of reasonable discretion.

The rule imposes a heightened standard of care on a professional trustee commensurate with the trustee's "special skills or expertise” (UPIA, sec. 2[f]; Restatement [Third], sec. 77[3]). To ensure that individual portfolio managers stay within the band of reasonable discretion, institutional trustees typically require the preparation of "a written investment policy statement for each new trust account, reciting investment guidelines that reflect the purpose of the trust and the risk tolerance of the beneficiaries” (Dukeminier and Sitkoff 2013, p. 634). An investment policy statement will normally specify "risk, return, and time horizon parameters" and will define "diversification and rebalancing guidelines" (fi360 2013, p. 47). Among other benefits, this practice facilitates " $[r]$ ebalancing ... to maintain proper diversification," ensuring that the "portfolio avoids 'allocation drift' by not straying far from its targeted levels of risk and return” (fi360 2013, p. 48). Moreover, an investment policy statement memorializing the trust's target asset allocation and the trustee's reasoning for that target provides a "“paper trail' in the event of an audit, litigation, or a dispute" (fi360 2013, p. 48). Consistent with the higher standard of care expected of a professional trustee, courts have rebuked bank trustees for failing in a timely manner to "establish an investment plan" (see, for example, In re Estate of Janes, 681 N.E.2d 332, 338 [1997]; In re Hunter, 955 N.Y.S.2d 163, 165 [2012]).

\section{A Corollary Reform}

The embrace of portfolio-as-a-whole investing by the prudent investor rule brought into view the need for a corollary reform. Trusts commonly provide for "income" to be paid to a life beneficiary, with the "principal" to be paid to a remainder beneficiary at the life beneficiary's death. Under traditional law, the form of an investment return determines its classification as income or principal. Rents, cash dividends on common stock, and interest on bonds are classified as income, but increases in asset value such as stock or land appreciation (and so realized capital gains) are classified as principal. Accordingly, the duty to produce a "reasonably appropriate" level of income that fairly balances the interests of the income and principal beneficiaries sometimes compelled the trustee to skew the trust's investment program toward interest and dividends or toward capital appreciation. ${ }^{8}$ Such skewing is in obvious tension with portfolio theory (Langbein 1996, pp. 667-68).

\footnotetext{
${ }^{8}$ Suppose $H$ devises property to $X$ in trust to distribute the income to his surviving wife, $W$, for life, and on her death to distribute the principal to his daughter, $D$. As trustee, $X$ has "a duty to so invest and administer the trust, or to so account for principal and income, that the trust estate will produce income that is reasonably appropriate to the purposes of the trust and to the diverse present and future interests of" $W$ and $D$ (Restatement [Third], sec. 79[2]).
} 
To reconcile principal-and-income accounting with portfolio theory and the prudent investor rule, per the Appendix Table every state except one has adopted at least one of two corollary reforms. The first is a power to adjust, meaning a power to reclassify returns as principal or income irrespective of their form (see Uniform Principal and Income Act [1997], sec. 104). The second is the so-called unitrust, under which income is redefined as a specific percentage of the trust corpus. The tax treatment of these reforms, however, was unsettled until Treasury regulations recognizing the reforms for federal tax purposes took effect in 2004 (see Treas. Reg., sec. 1.643[b]-1). In consequence, most states enacted their reforms in 2004 or shortly thereafter. ${ }^{9}$ Although this clustering of enactments complicates testing the independent effect of principal-and-income reform, we report some results controlling for principal-and-income reform and some with the sample cut in 2004.

\section{The Rule in Practice}

Absorbing modern portfolio theory into the law of trust investment by way of the prudent investor rule has intuitive appeal. But whether the rule has been applied properly in practice, and indeed, whether the law reform has even affected practice, are empirical questions that are distinct from the soundness of the reform in theory. Prior to the reform, some scholars had suggested that the prudent man rule had endured for so long even after widespread acceptance of portfolio theory in part because sophisticated parties had opted out of its application (Gordon 1987; Langbein and Posner 1976). Strong survey and abundant anecdotal evidence indicates that such opt outs were in fact common (see, for example, New York State Bankers Association 1964, pp. 20, 27).

The effect of those opt outs in practice, however, is unclear. Typical boilerplate opt-out language did not adopt a portfolio standard, but rather purported to free the trustee from compliance with trust investment law altogether. ${ }^{10}$ But "for reasons of policy trust fiduciary law" cannot be waived in its entirety (Restatement [Third], sec. 96, comment c; see also Langbein 2004). ${ }^{11}$ To the contrary, it is "a basic principle of trust administration" that "all powers held in the capacity of trustee must be exercised, or not exercised, in accordance with the trustee's fiduciary obligations" (Restatement [Third], sec. 70, comment a). As such, "the fact that an investment is permitted does not relieve the trustee of the fundamental duty to act with prudence. The fiduciary must still exercise care, skill, and caution in making decisions to acquire or retain the investment” (Restatement [Third], sec. 91, comment f). Prior to the reform, therefore, even in a trust with an opt-out clause the trustee was subject to judicial review of each investment in isolation without regard to the expected risk and return of the portfolio as a whole.

A further structural point is that the paradigmatic professional trustee-a bank trust department—is typically compensated by a small percentage of corpus (fewer than 100 basis

\footnotetext{
${ }^{9}$ Moreover, several of the earlier enactments were revised soon after the regulations to conform to them.

${ }^{10}$ For example, a formbook published by Citibank in 1977 suggested giving the trustee a power " $\mathrm{t}$ ]o invest and reinvest in property of any character, real or personal, foreign or domestic, including, without limitation, bonds, notes, debentures, mortgages, certificates of deposit, common and preferred stocks, ... without regard to the proportion which such property or property of a similar character, so held, may bear to the entire amount of the trust estate, whether or not such property is of the class in which trustees are authorized by law or any rule of court to invest trust funds" (Citibank, N.A. 1977, p. 43).

${ }^{11}$ In the leading case of McNeil v. McNeil (798 A.2d 503, 509 [2002]), the Delaware Supreme Court put the point thus: "A trust in which there is no legally binding obligation on a trustee is a trust in name only and more in the nature of an absolute estate or fee simple grant of property."
} 
points). For such a trustee, avoiding litigation risk is a more salient consideration in portfolio construction than pursuit of additional compensation through portfolio growth. ${ }^{12}$ Under the prudent man rule, however, litigation risk was asymmetric, because the rule was focused on avoiding risk. Under the prudent investor rule, by contrast, trustees are exposed to litigation risk for both too much and too little exposure to market risk. "Beneficiaries can be disserved by undue conservatism as well as by excessive risk-taking” (Restatement [Third] sec. 90, comment $\mathrm{e}[1])$.

In Schanzenbach and Sitkoff (2007), we found that after a state's adoption of the prudent investor rule, institutional trustees held about two to four percentage points more stock than before, predominately at the expense of government bonds and other investments deemed "safe" by prior law. ${ }^{13}$ This effect increased over time, which we attributed to the transaction costs of portfolio reallocation and the rule's allowance of a "reasonable time" to bring an existing portfolio into compliance with the rule. We therefore concluded that the rule freed trustees to invest more heavily in stock, and that the emphasis on risk avoidance under the prudent man rule had constrained trustee investment. Moreover, as detailed in Figure 2 and Table 1 below, the share of trust corpus invested in stock increased by roughly 15 percentage points over the 1990s, of which our results explain at most one-third. Because our estimation strategy focused on portfolio reallocation directly attributable to a state's statutory adoption of the rule, we could not identify whether the rest of this increase traced to a secular trend or the more general influence of the Restatement [Third] and UPIA separate from state-level statutory adoption.

After the financial crisis of 2008, some scholars and practitioners questioned whether reorientation from risk avoidance to risk management was sound. Relying in part on our prior finding of increased stockholdings after the reform, some have argued that, in the years leading up to the financial crisis, trustees assumed too much market risk (see, for example, Sterk 2010; Hofri-Winogradow 2014, 2015; Dagan and Hannes 2014). On this assumption of failed risk management, a question we did not examine empirically in our prior study, some have urged repeal of the prudent investor rule, replacing it with safe harbors or lists of approved investments (Sterk 2010; Getzler 2009).

At stake in this debate is not just the law governing trust investment, but fiduciary investment generally, which touches trillions of dollars. The Uniform Prudent Management of Institutional Funds Act, promulgated in 2006 and since adopted by almost every state, applies the prudent investor rule to the management of charitable endowments. A version of the rule is adopted by the Employee Retirement Income Security Act of 1974, which governs the investment practices of the fiduciaries of most pension funds (29 U.S.C. sec. 1104[a]; see also 29 C.F.R. sec. 2550.404a-1[b]). The rule has been adopted in England and most of the British

\footnotetext{
${ }^{12}$ For trusts in which high-power incentives are desired, the usual structure is a directed trust or private trust company (see Dukeminier \& Sitkoff 2013, pp. 654-55, 657).

13 There has been little other empirical study of the prudent investor rule. Longstreth (1986) surveyed the 50 largest bank trust departments, college and university endowments, private foundations, and corporate pension fund sponsors. Of the institutions replying, bank trust departments, then operating under the prudent man rule, reported being the most constrained by fiduciary investment law. Begleiter (1999) surveyed 239 banking institutions in Iowa about their interpretation of the Iowa enactment of the prudent investor rule. Of the 61 institutions replying, a substantial majority indicated that they employed risk-and-return analysis in making trust investments. Using Securities and Exchange Commission (SEC) filings, Hankins, Flannery, and Nimalendran (2008) and Del Guercio (1996) found that bank trust departments tended to invest conservatively, but more heavily in non-dividend paying stock after adoption of the rule. However, their SEC data does not distinguish between personal trusts and other funds not covered by state-level fiduciary investment law, such as pension funds governed by the Employee Retirement Income Security Act of 1974.
} 
Commonwealth (Getzler 2009, pp. 238-39). And the rule influences the norms of fiduciary investment practice even in fields in which it has not been adopted expressly (Sitkoff 2014b, p. 48).

\section{Data}

To test the effect of the prudent investor rule on trustee management of market risk, we analyze changes in stock holdings by trust size and the changing relationship between trust assets and the S\&P500 after adoption of the rule. Our data come from two sources: (a) the Federal Deposit Insurance Corporation's Statistics on Depository Institutions, ${ }^{14}$ and (b) the Internal Revenue Service's state-level summaries of personal trusts filing Form 1041 (U.S. Income Tax Return for Estates and Trusts). ${ }^{15}$ The FDIC data contain information on trust corpus and stock holdings, while the IRS data report fiduciary fees, which proxy for trust corpus.

\section{A. The FDIC Data}

The FDIC collects detailed annual financial data on "personal trust" accounts from all institutions that are subject to supervision by federal banking authorities. ${ }^{16}$ The data are at the bank level; individual account data are not reported. However, the number of accounts is reported, hence we can compute average account size at the bank, state, and national levels.

Between 1986 and 2008, the allocation of personal trust holdings in reporting institutions were reported across ten separate categories, including "stocks." Mutual funds with a mix of stocks and bonds are reported as "stock," while pure bond funds, money market mutual funds, and municipal bond funds are reported as "bonds," "money market funds," and "municipal bonds" respectively. ${ }^{17}$ The bulk of non-stock assets are U.S. Treasuries, municipal bonds, interest bearing accounts, and money market mutual funds. ${ }^{18}$ After 2008, the FDIC continued to report total trust assets and number of personal trust accounts, but it no longer reported holdings by investment category within personal trusts. In consequence, although we can examine total trust assets in the FDIC data through 2012, we can examine the breakdown among the different investment categories only through 2008.

The FDIC data identify the reporting institution and the state in which it is headquartered, which allows us to undertake analysis at the state and bank levels in addition to the national level. For a trust with an institutional trustee and a choice-of-law provision, the normal practice is to select an institution located in the state whose law is chosen to ensure that the set-

\footnotetext{
${ }^{14}$ Available at http://www2.fdic.gov/sdi/main.asp.

${ }^{15}$ Available at http://www.irs.gov/uac/Tax-Stats-2, with additional years available from the authors upon request.

${ }^{16}$ The data are categorized as "Employee Benefit," “Personal Trusts,” and "Estates.” We examine only the personal trust category, which includes both private and charitable trusts. Within that category, we examine only those accounts that the bank classifies as "managed," meaning trusts in which the bank, as trustee, as investment management discretion. Sitkoff and Schanzenbach (2005, pp. 387-390, 434-35) describes these data in greater depth.

17 The inclusion in our "stock" variable of mutual funds with stocks and bonds is not a concern for two reasons. First, we use the "stock" variable as a measure of exposure to market risk rather than as a pure measure of stockholdings in particular. Second, the stock variable is highly correlated with the S\&P 500, implying that "stock" does indeed comprise mainly stocks and is a suitable proxy for exposure to market risk. In Table 6, for example, we find the correlation between changes in "stock" and S\&P 500 is 0.86 across all years.

18 The remaining categories of “other bonds," "real estate,” and “miscellaneous” investments resist obvious classification as safe or risky, but generally compose less than 5 percent of national trust assets.
} 
tlor's choice of law will be followed (see, for example, Sterk [2003], pp. 2101-04). For a trust without a choice-of-law provision, the prevailing default rule is that the administration of the trust is governed by the law of "the principal place of administration, which normally is located at the place of business of the corporate trustee or the residence of the individual trustee" (Scoles 2002, p. 237). Accordingly, at least prior to 1997, when interstate branching was uncommon (see McLaughlin 1995), we may safely assume strong correlation between reported state and governing law.

Federal banking reform that took effect in 1997, however, eased restrictions on interstate banking and branching. ${ }^{19}$ Interstate bank mergers and branch consolidation add noise to state- and bank-level analyses of the data, but not national-level analysis. Assets held by a branch in state $A$ are likely governed the law of state $A$. But if the headquarters of the reporting institution is in state $B$, the branch's assets may be reported as held in state $B$. As such, sizeable bank consolidations and mergers, as took place in the early 2000s, could affect our state- and bank-level analyses, particularly in specifications that test changes in a particular state's law, by confounding our coding of governing state law. To address this concern, in addition to specifications that examine only national data, as a further robustness check we report some results that cut the data in 1997.

Because several of our identification strategies consider total assets and average account size, we must also consider the possibility of noise from jurisdictional competition for trust business. Beginning in the late 1990s, state trust laws became significantly differentiated on a handful of margins in response to lobbying by local bankers and lawyers, who sought to attract out-of-state trust business. In Sitkoff and Schanzenbach (2005), we found that certain of these reforms were associated with substantial increases in reported trust assets and average account size. ${ }^{20}$ Accordingly, in some specifications we undertake national-level analysis, cut the data in $1997,{ }^{21}$ or control directly for these reforms (as well as principal-and-income reform). These robustness checks suggest that jurisdictional competition has not biased our prudent investor rule estimates.

Because the FDIC data includes only trusts for which a reporting institution is the trustee, it is not representative of the full population of trust funds. For example, trusts with an individual trustee, such as a relative or a lawyer, or with an institutional trustee that is not regulated by federal banking authorities, such a private trust company, are not in the data. ${ }^{22}$

\footnotetext{
${ }^{19}$ The statute, Riegle-Neal Interstate Banking and Branching Efficiency Act of 1994, Pub. L. No. 103-328, 1994 U.S.C.C.A.N. (108 Stat.) 2338 (1994) (codified at 12 U.S.C. § 1811), was enacted in 1994 but the reform at issue did not take effect until 1997.

${ }^{20}$ The principal effect was in states that authorized perpetual trusts and did not levy a fiduciary income tax (Sitkoff and Schanzenbach [2005], pp. 410-11).

${ }^{21}$ With the single exception of perpetual trusts in Delaware, all the jurisdictional competition reforms were enacted in 1997 or later (see Sitkoff and Schanzenbach [2005], pp. 430-33, tbl. 1).

${ }^{22}$ The Director of the South Dakota Division of Banking tells us that at year-end 2013, there were 28 private family trust companies in that state with $\$ 54.58$ billion in assets.
} 


\section{B. The IRS Data}

The IRS data are state-level aggregations of page one of IRS Form 1041, the fiduciary income tax return. A trustee of a trust other than a "grantor trust" must file a 1041 in the year following any year in which the trust earns income. ${ }^{23} \mathrm{~A}$ "grantor trust" is one in which the settlor's retained control warrants treating the property as belonging to the settlor for income tax purposes, such as if the trust is revocable (see I.R.C. §§671-77). ${ }^{24}$ The data include the number of nongrantor trust income tax returns filed, taxable income and source, and allowable deductions for calendar years 1997 and 2000 through 2011, corresponding to filing years 1998 through 2012.

Because almost every state had adopted the prudent investor rule by the early 2000s, and 40 states had adopted the rule by 1997, the IRS data are not suitable for direct examination of the effect of the law reform. ${ }^{25}$ However, the IRS data includes information on fiduciary fees, which are a deductible expense against gross income. Fiduciary fees are usually levied as a percentage of trust corpus, so yearly changes in reported fiduciary fees proxies for yearly changes in total trust corpus. Accordingly, in some specifications we use yearly changes in the fiduciary fees deduction as an alternative measure to yearly changes in total corpus as reported in the FDIC data. In interpreting these results, however, we caution that reported fiduciary fees may be less volatile than trust corpus, as most professional trustees use graduated fee scales with diminishing percentages for larger trusts (see, for example, Dukeminier and Sitkoff [2013], pp. 650 n.101, 654 n.106).

The sample of trusts in the IRS data overlaps only in part with the FDIC data. Each includes some trusts that are not included in the other. Because the IRS data includes all nongrantor trusts that earned income in the relevant year, it includes a variety of professional trustees, such as lawyers and private trust companies, that are not included in the FDIC data. ${ }^{26}$ The FDIC data, by contrast, include all trusts, including grantor trusts, that have a reporting institution as trustee, but no trusts in which the trustee is an individual or nonreporting institution.

\section{Descriptive Statistics}

Figure 1 depicts the number of accounts and average account size in the FDIC data from 1986 to 2012. The number of reported accounts declined during this period, which could

\footnotetext{
${ }^{23}$ In the jargon, we are speaking of trusts that for federal income tax purposes qualify as a "simple trust" or as a “complex trust." The federal income taxation of trusts is governed by Subchapter J of the Internal Revenue Code (I.R.C. §§640-85). For a survey explanation, see Sherman (1998). Form 1041 is also filed by the fiduciaries of decedent's estates, bankruptcy estates, certain disability trusts, and pooled income funds, none of which is included in our analysis.

${ }^{24}$ Other examples include irrevocable trusts in which the settlor or the settlor's spouse has discretionary power over, or is entitled to distributions of, income or principal (Dukeminier and Sitkoff [2013], pp. 978-79). Although originally meant to prevent abuse, the grantor trust rules are today widely used for tax avoidance (see Ascher [2011]).

${ }^{25}$ The state-level aggregations are based on the trustee's address as indicated on the 1041. Because this address need not be in the state whose law governs the administration of the trust, coding governing law for the IRS data faces similar problems to that in the FDIC data. However, we do not use the IRS data, which almost entirely postdates the law reform, to test the effect the reform directly, but rather to examine correlation between changes in trust corpus and the S\&P500.

${ }^{26}$ Unpaid amateur trustees of nongrantor trusts are also included in the IRS data, but they are not included in our analysis, as we examine fiduciary fees paid.
} 
reflect the growth of nonreporting institutional trustees such as private trust companies. Real average account size fluctuates, in part corresponding to market fluctuations, but overall it has grown in the period under study.

Figure 2 traces the percentage of trust assets in the FDIC data held in stock versus in "safe" assets, meaning government bonds, insured deposits, and money market funds, from 1986 to 2008. There are clear, mirror-image trends, with stock holdings increasing and "safe" holdings decreasing in the years after promulgation of the prudent investor rule in the Restatement [Third] in 1992 and UPIA in 1994. Apart from the market crashes in 2002 and 2008, stock holdings have averaged between 60 and 70 percent of yearly trust corpus, while "safe" holdings have averaged between 22 and 28 percent. The remainder comprises corporate bonds and real estate.

Figure 3 depicts the number of returns and fiduciary fees per return in the IRS data. The number of returns has grown slowly across the period under study, rising from 1.9 million in 2000 to 2.03 million in 2011. Real fiduciary fees per return have varied between $\$ 1,600$ and $\$ 1,800$. As with average account size in the FDIC data, fiduciary fees exhibit declines in 2002 and 2008, suggesting declines in trust assets when the markets crashed.

Table 1 presents summary statistics for both data sets. The top half presents yearly averages for the FDIC data, and breaks the data into three time periods: (a) 1986-1994, (b) 19952000, and (c) 2001-2012. We choose 1994 as our first breakpoint, because that is the year the UPIA was promulgated, just two years after the Restatement was updated, and it coincides with the beginning of the bull market of the mid-1990s. We choose 2000 as our second breakpoint, because by 2001 all but three states had adopted the rule, and the stock market experienced increased volatility over the 2000s, with major drops in 2001, 2002, and 2008, followed by significant rebounds. Despite increased market volatility in the 2000s, and the run up in stock prices in the mid to late 1990s, the percent of trust assets invested in stock was quite similar in both time periods, roughly 15 percentage points higher in than in the first period of 1986-1994.

Our empirical strategy for investigating whether market risk exposure was aligned with beneficiary risk tolerance is to examine how trusts of different sizes responded to changes in the rule. Because we do not have individual account data, we proxy for trust size by the average account size at the bank or state level in the FDIC data and by fiduciary fees per return at the state level in the IRS data. The bottom half of Table 1 reports average account size as well as at the 90th, 75th, 50th, and 25th percentiles computed across all years for the FDIC data at the state and bank level and for the IRS data at the state level. Imputed average account size varies widely across states and banks. In both the FDIC and the IRS data, the 75th percentile stateyear observation is roughly twice that of the 25th percentile state-year observation.

\section{Analysis and Results}

The increase in stockholdings following the prudent investor rule raises the important question of how exposure to market risk has been managed after the rule. The rule "does not call for avoidance of risk," but rather for "prudent management of risk. ... [I]t is essential to recognize that compensated risk is not inherently bad” (Restatement [Third], sec. 90, comment e[1]). Our analysis considers two aspects of prudent management of market risk: (a) alignment of market risk exposure with beneficiary risk tolerance, and (b) ongoing management of market risk exposure and portfolio rebalancing. 
We examine alignment of market risk exposure with beneficiary risk tolerance before and after the prudent investor rule by assessing the correlation between reported stockholdings and bank average trust account size, our proxy for beneficiary risk tolerance. John Langbein, the principal drafter for the UPIA, predicted in 1996 that the reform would not induce trustees of risk intolerant trusts to take on much additional market risk. He reasoned that, for such trusts, "the outer reaches of the risk/return distribution will be every bit as unsuitable as before. What has changed is that the trustee is now able to examine the risk tolerance of each particular trust and to tailor that trust's investment policy accordingly" (Langbein 1996, p. 650). By examining the correlation between risk tolerance (proxied by average account size) and increased stockholdings, we assess the validity of that prediction. If in practice the rule prompted a significant increase in stockholdings among small trusts, or an unreasonably large increase in stockholdings for mid-sized trusts, then the critics' claims about imprudent risk management would find support in our sample data.

We examine ongoing management of market risk exposure and portfolio rebalancing by assessing the correlation between yearly changes in aggregate trust corpus and yearly changes in the S\&P 500 before and after the rule. Two offsetting effects may be present. First, increased stockholdings after the rule's adoption should increase the correlation between changes in trust corpus and changes in the market. On the other had, increased rebalancing of portfolios in accordance with the rule's imposition of an "ongoing duty to monitor investments and to make portfolio adjustments if and as appropriate" (Restatement [Third], sec. 90, comment e[1]) should dampen the correlation. Among institutional trustees, rebalancing follows naturally from the establishment of a target asset allocation in an investment policy statement. "Once the target allocation is established, periodic rebalancing is necessary to maintain the intended risk-return profile of the portfolio” (fi360 2013, p. 48).

\section{A. Alignment of Market Risk with Beneficiary Risk Tolerance}

We begin our analysis by assessing sensitivity to risk tolerance in trust portfolio design. The heart of the prudent investor rule is the command to trustees to implement "an overall investment strategy having risk and return objectives reasonably suited to the trust" (UPIA, sec. 2[b]; see also Restatement [Third], sec. 90[a]). We look to stock holdings as our measure of market risk exposure, treating non-stock holdings as less exposed to market risk or risk-free (e.g., government bonds, insured deposits, and money market funds). We take average trust account size as a proxy for beneficiary risk tolerance, reasoning that on average larger trusts will have more risk tolerant beneficiaries and therefore should be more aggressively invested. ${ }^{27}$ On this assumption, if trustees are sensitive to beneficiary risk tolerance, we would expect to observe greater increases in trust stockholdings in banks with larger average trust account sizes than those with smaller average trust account sizes.

Figure 4 depicts the percent of trust assets held in stock for each quartile of average account size in the FDIC data between 1986 and 2008. We also include the 90th to 100th percentiles as a separate category, because the average account size in this group is much larger than the rest. Percent stock holdings line up in Figure 4 as expected. The lowest quartile of banks by average account size hold only 10 to 20 percent of trust assets in stock, whereas the top quartile held between 40 and 50 percent of trust assets in stock, and the top five percent held 45 to 65 percent of trust assets in stock. Because the bulk of the remaining non-stock holdings are in

\footnotetext{
${ }^{27}$ Other factors relevant to risk tolerance, including the beneficiaries’ age and other wealth, but we lack such data.
} 
"safe" assets, Figure 4 implies that as average account size increases, the trustees in our sample increased exposure to market risk accordingly.

The changes over time also tell an important story. Stock holdings for all quartiles increased in the period following the promulgation of the Restatement [Third] and UPIA in 1992 and 1994 respectively. By the 2000s, each quartile's stock holdings had leveled off at about ten percentage points higher relative to their levels in the late 1980s and early 1990s.

\section{Estimation strategy}

We frame our more formal analysis by exploring heterogeneity across states and banks using quantile regressions. Assuming that average trust account size is a good proxy for beneficiary risk tolerance, then a positive correlation between average account size and stock holdings would imply trustee sensitivity to beneficiary risk tolerance. This dynamic would be missed by an OLS analysis of the average effect. ${ }^{28}$ We therefore use the following log-log specification in which the coefficient on the S\&P500 is interpreted as the percentage change in trust assets that results from a one-percent change in the S\&P500.

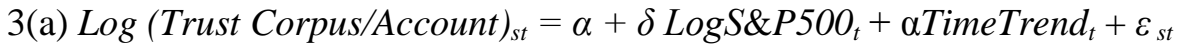

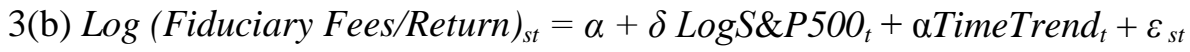

where $t$ indexes time and s indexes state. We do not include state dummies because we are interested in differences in correlations across the distribution of states rather than changes within a state. Regressions with and without time trends yielded very similar results, but we report results with time trends.

The results of these regressions are reported in Table 2, both for OLS regressions and for quantile regressions at the 25th, 50th, and 75th percentiles of bank average trust size (\$168,000, \$340,000, and \$570,000). The results demonstrate heterogeneity at the state and bank level. Qualitatively, changes in trust holdings in states and at banks with smaller conditional average account sizes are less correlated with changes in the S\&P 500 than those with larger average account sizes. Inter-quartile regressions for state-level results did not reject differences between the quartiles, but there is a statistical difference (p-value $<0.01$ ) between the 25th and 75th percentiles.

Table 2 shows that the greatest heterogeneity is at the bank level. We therefore undertake a locally weighted regression of log account size on percentage stock holdings at the bank level, with average account size deflated by the CPI. Two lowess curves are presented in Figure 5-one for banks in states that adopted the prudent investor rule, the other in states with the old law. The curves show an approximately linear relationship for much of the distribution, though above the 90th percentile the relationship flattens. Stock holdings in banks in the 25th percentile and below are more or less the same regardless of the applicable legal regime. Accordingly,

\footnotetext{
${ }^{28}$ Variation in trust corpus can arise from sources other than changes in the market value of assets. Changes in the number of accounts or returns cause changes in asset levels as more trusts are created or terminate. Moreover, natural variation is larger at the state and bank level than the national level. Consequently, to reduce the variation in assets caused by changes in the number of accounts at the state level, we denominate our state level results by accounts or returns. Generally, the results were more precisely estimated when the dependent variable was denominated by accounts and returns, though the magnitude of the effects were little changed.
} 
the effect of the reform appears most pronounced among banks with average account sizes in the 25th to 90th percentiles.

We take the non-parametric estimates provided by the lowess curves in Figure 5 as motivating breaks at the 25th and 90th percentiles. We therefore estimate the following regression at the bank level:

(4) Percent Stock ${ }_{b s t}=\alpha+\gamma_{1}$ AveAccount $25-90^{\text {th }}$ pntl $+\gamma_{2}$ AveAccount25 $>90^{\text {th }}$ pntl bst $_{\text {bt }}$ $+\beta_{1}$ Prudent $_{\text {st }} \mathrm{x}$ AveAccount $25<25_{\text {bst }}$ $+\beta_{2}$ Prudent $_{\text {st }} \times{\text { AveAccount } 25-90^{\text {th }} \text { pntl }}$ $+\beta_{3}$ Prudent $_{s t} \mathrm{X}$ AveAccount $25>90^{\text {th }}$ pntl bst $_{\text {bs }}$ + Fixed Effects(state, holding company, year) $+\varepsilon_{\text {bst }}$

which allows the effect of the prudent investor rule on stock holdings to vary based on the average account size of the bank. The regression uses the bank-level panel, with bank percent stock holdings as the dependent variable. In most regressions, we include holding company fixed effects on the premise that a corporate parent may be an important determinant of investment policies as well as opportunities to participate in pooled investment vehicles (if there is no parent, we used the bank's unique identifiers). Average account sizes are calculated in real dollars and indicator variables are included for a bank's place in the distribution of real average account sizes between 1986 and 2008. These indicators are then interacted with Prudent ${ }_{s t}$, allowing the effect of the prudent investor rule to be different for banks with larger or smaller average accounts.

We also undertake event studies with leads and lags of reform, which helps isolate the effect of the rule. The leads of the event studies assess whether there were potentially biasing pre-trends in states that adopted the rule, while the lags assess whether the rule had a delayed effect. In recognition of the tax and other transaction costs of portfolio reallocation and the possibility of illiquidity, the rule expressly allows for a "reasonable time" to bring an existing portfolio into compliance with the rule (UPIA, sec. 4; Restatement [Third], sec. 92). In our prior study, we found that the rule had an increasing effect over time (Schanzenbach and Sitkoff [2007], pp. 698, 706).

The event studies are also important because the percentage stock held in a bank's trust accounts and its average account size are potentially simultaneously determined. More equity probably means higher returns in the long run and so larger average account sizes. Results on the short-run effect of reform should not exhibit this bias. Finally, assessing the short-run effect of reform isolates the effect of the prudent investor rule from other law changes, such as principal-and-income and jurisdictional competition reforms, because these other reforms were generally adopted well after the prudent investor rule.

\section{Results}

The first column of Table 3 reports a simple regression showing percentage stock holdings before-and-after adoption of the prudent investor rule. We find an economically meaningful and statistically significant increase of 3.34 percentage points in stock holdings. ${ }^{29}$

${ }^{29}$ This coefficient is larger than the results reported in Schanzenbach and Sitkoff (2007), which were on the order of 2.2 percentage points. We attribute the difference to the longer sample period used in the present study. 
The remaining columns break out the effect of the prudent investor rule as specified in Equation 4. In column 2, the coefficient on Prudent Investor for banks below the 25th percentile is -2.2 and is not statistically significant. By contrast, for banks with mid-range (25th to 90th percentiles) or very large (above 90th percentile) average account sizes, the rule has a positive effect of 3.7 and 3.1 percentage points respectively, and these findings are significant at the 0.01 level.

When holding company fixed effects are added in Column 3, the effect of the rule on banks with mid-range account sizes increases slightly to 4.2, but the effect of reform for banks with large accounts is only 0.77 and is not statistically significant. The results in Column 4, which includes state-specific time trends, are similar - a coefficient of about 5 for mid-range banks and a small and imprecisely estimated effect for banks with large accounts. The coefficient on the effect of reform for banks with trust sizes below the 25th percentile is positive when we include bank holding company fixed effects in columns 3 and 4, but remains statistically insignificant.

Reform to principal-and-income accounting rules may have created more flexibility in portfolio design, and bank mergers and jurisdictional competition risk confounding our analysis. Columns 5 through 7 address these concerns. In Column 5, in which we control for principaland-income reform and the main jurisdictional competition reforms through 2008, the coefficients of interest barely change. In Column 6, we cut the data in 2004, which should remove most of the effect of principal-and-income reform. Some of the coefficients of interest change, but all remain within the range of the estimates of Columns 2 through 5 . The main coefficient of interest, the estimate of the effect of the rule on stock holdings in banks with average account sizes in the 25th to 90th percentiles, falls to 3.7 from 4.1 in Column 3 but remains significant at the 0.01 level. In Column 7, we cut the data in 1997, which is prior to the merger problem and nearly all of the main jurisdictional competition reforms. The estimate of the effect in the 25th to 90 th percentiles falls to 2.4 but again remains strongly significant.

It is hard to assess whether the coefficient changes in the robustness checks of Columns 6 and 7 indicate that the estimates using the full sample are biased upward. First, the estimates in Column 5, in which we control directly for principal-and-income reform and jurisdictional competition across the entire period under study, do not show the same diminishment. Second, the effect of the prudent investor rule should increase over time, as the rule allows for a "reasonable time" in light of transaction costs to bring an existing portfolio into compliance (UPIA, sec. 4; Restatement [Third], sec. 92).

To allow for the possibility of a lagged effect, and to rule out a pre-reform trend, we undertake an event study that allows for leads and lags around enactment of the reform. Table 4 presents our results for the entire sample (Columns 1 and 2), the years 1986 through 2004 (Columns 3 and 4), and the years 1986 through 1997 (Columns 5 and 6). For each sample, we report a specification with lags and with leads and lags. The coefficients on leads and lags are presented only for banks with average account sizes in the 25th to 90th percentiles. The coefficients for the other percentiles, which are not statistically significant, are suppressed for ease of presentation.

When the entire sample (Columns 1 and 2) or only data through 2004 (Columns 3 and 4) are examined, for banks with average account sizes in the 25th to 90th percentiles we find a small effect in the year the prudent investor rule took effect, a clearer effect within 2 years, and an increasingly larger and more significant effect with more time. When we cut the data in 
1997 (Columns 5 and 6), the same pattern is evident, though somewhat attenuated. The increasing effect of the rule over time is consistent with transaction costs in portfolio reallocation, which is contemplated by the rule's allowance for a "reasonable time" to bring an existing portfolio into compliance (UPIA, sec. 4; Restatement [Third], sec. 92). The regressions including leads (the even numbered columns) suggest that there was no pre-trend or significant changes just prior to the rule's enactment.

\section{Discussion}

Our findings on alignment of market risk exposure with beneficiary risk tolerance suggest that, although stockholdings increased after the rule (Schanzenbach and Sitkoff [2007]), that increase traces entirely to banks with average trust account sizes in the 25th percentile and above. In particular, for banks in the 25th to 90th percentiles, there is a statistically and economically significant increase in stock holdings, and this effect is robust to the inclusion of different controls and bank holding company fixed effects. The effect of the rule on banks with mid-sized average account sizes is reduced when we shorten the time period under consideration. This reduction in observable effect could reflect the allowance of a "reasonable time" to bring an existing portfolio into compliance with the rule, the importance of the companion reform to principal-and-income accounting rules, or both.

Stockholdings by banks with average trust account sizes below the 25th percentile were unaffected by the reform. Although in some specifications the point estimate for these banks is positive, in other specifications it is negative and zero, and the estimate is never close to statistical significance. Based on the non-parametric results from the lowess curves, we interpret these results as consistent with a null effect. Taking average account size as a proxy for risk tolerance, these results suggest compliance with the rule's command to align market risk exposure with beneficiary risk tolerance. As predicted by Langbein (1996), trustees did not move outward on the risk/return curve after the reform for the least risk tolerant trusts.

For banks with an average account size at the 90th percentile and above, the estimated effect of the rule is sensitive to whether we include bank holding company fixed effects, but the coefficients are consistently positive. There are at least two reasons why the effect of the reform might have been attenuated for the largest trusts. First, because such trusts had larger stockholdings to begin with, a further increase in stockholdings would amount to a relatively smaller percentage and so would be harder to measure. Second, to the extent an opt out might have been effective, for example if it contained customized rather than boilerplate language, we conjecture that such an opt out is more likely to be found in the largest trusts, for which the settlor would be more likely to incur the costs of custom language. Given the inconsistent empirical results and the plausibility of multiple, which are not mutually exclusive, we draw no firm conclusions on the effect of the reform on the largest trusts.

\section{B. Ongoing Management of Market Risk}

To assess ongoing management of market risk, we examine the correlation between yearly changes in reported aggregate trust assets (FDIC data), average account sizes (FDIC data), and fiduciary fees per return (IRS data) and yearly changes in the S\&P 500, which we take 
as our model of the market. ${ }^{30}$ Comparing the correlation between trust corpus and the S\&P500 before and after the rule assesses the extent to which the increase in market risk after the rule, evidenced by Figure 2 and Table 1, has been managed on an ongoing basis such as by portfolio rebalancing.

Figure 6 depicts year-to-year percentage changes in the S\&P 500 and aggregate trust corpus in the FDIC data. Because trust corpus is reported as of December 31, for analysis of the FDIC data we use the year over-year-change in the S\&P 500 as our measure of change in the market. When the S\&P rises or falls, trust corpus does likewise, but to a lesser degree. Indeed, for most years, the percent yearly change in trust corpus was approximately one-half that of the S\&P 500. Figure 6 thus implies that, in general, trust assets are about one-half as volatile as the market.

Figure 7 is the IRS data analogue to Figure 6, linking yearly changes in fiduciary fees per return with yearly changes in the S\&P 500. Because fiduciary fees are assessed over the course of the year based on periodic valuations of the trust corpus, commonly monthly or quarterly, for analysis of the IRS data we take the yearly change in the monthly average of the S\&P 500 as our measure of change in the market. As with Figure 6, when the S\&P 500 rises or falls, fiduciary fees do likewise, but generally by about half as much.

Although we hesitate to focus too much on one or two data points in isolation, a comparison of Figures 6 and 7 points to an anomaly in 2009 that warrants further discussion. Consistent with the general trend across in both graphs, in Figure 7 fiduciary fees fall in 2009 about half as much as the decline in the S\&P 500. In Figure 6, by contrast, total corpus falls but the year over year change in the S\&P 500 is positive. This anomaly, with the S\&P 500 being shown as decreasing in one graph and increasing in another in the same year, is an artifact of the different manners by which we computed changes in the S\&P 500 for the two graphs. Alone among the years under study, in 2009 the S\&P 500 experienced a sharp decline in the first part of the year, followed by a sharp recovery and ultimately an increase relative to the beginning of the year. Accordingly, in Figure 7, for which we computed the change in the S\&P 500 as the yearly change in the monthly average of the S\&P 500, shows a decrease in the S\&P 500. For Figure 6, by contrast, for which we computed the change in the S\&P 500 as its yearover-year change, there is an increase in the S\&P 500. In some specifications we exclude 2009 and subsequent years to verify that this anomaly does not drive our results.

Figure 8 refines Figure 6 by breaking out the aggregate trust corpus variable into its stock and non-stock components. The latter consists primarily of government and corporate bonds and real estate. The yearly change in non-stock assets is little related to the yearly changes in the S\&P 500 index, suggesting that these assets do not vary with the market. By contrast, the yearly change in stock is strongly related to the S\&P 500. These findings lend support for the use of the stock variable as a proxy for market risk and movement outward on the risk and return curve. ${ }^{31}$ Prior to 1996 , the yearly percent change in stock is nearly identical to the yearly

\footnotetext{
${ }^{30}$ Because trusts commonly provide for periodic distributions of income, we use S\&P 500 returns exclusive of cash dividends, which are classified as income under trust principal-and-income accounting rules. The results are not meaningfully different if we use S\&P 500 returns inclusive of cash dividends.

${ }^{31}$ Stock holdings are admittedly an incomplete measure of exposure to market risk. The non-stock portion of a portfolio might also be exposed to market risk (for example, real estate and corporate bonds), or might contain counterweights (for example, Treasuries may rise in downturns). We also have no information about which stocks comprise the stock holdings. Some stocks, such as public utilities, tend to be less volatile than the market, while others, such as small-caps or new technology offerings, tend to be more volatile. Across issues, common shares are riskier
} 
percent change in the S\&P 500. After the mid-1990s, trust assets become less responsive to positive market years than in the earlier period. However, in negative years (2000-2002 and 2008) the percent decline in trust stock assets is quite close to that of the S\&P500. We return to this point in our discussion of the regression analysis.

In sum, Figures 6, 7 and 8 suggest that the link between changes in trust assets and market returns has not varied much after the prudent investor rule. We next employ a variety of more formal analyses to confirm this result, which appears to reflect increased portfolio reallocation after the rule.

\section{Estimation Strategy}

We begin by estimating the national-level time-series relationship between changes in trust corpus and the market. Roughly speaking, we regress market returns on "returns" to trust assets. Of course, trust corpus does not change solely because of asset appreciation. Aggregate trust corpus may change as old trusts terminate and new trusts are created. Moreover, trust income is commonly distributed and trust principal may be invaded for distribution as well. We examine both the aggregate change in trust corpus as well as the change in average trust size, thus accounting for changes in the number of trusts outstanding. As is the case with most financial time series that are first differenced or based on returns, we verify that there is no serial correlation. The regression takes the form:

$$
\begin{aligned}
& \text { 1(a) } \% \Delta \text { Trust Corpus } \\
& t=\alpha+\delta \% \Delta S \& P 500_{t}+\varepsilon_{t} \\
& \text { 1(b) } \% \Delta \text { Fiduciary Fees } \text { Fid }_{t}=\alpha+\delta \% \Delta S \& P 500_{t}+\varepsilon_{t}
\end{aligned}
$$

We also separately assess the degree to which stock and non-stock assets are correlated with the market by separating trust corpus into stock and non-stock categories and re-estimating the equations. Thus, equations 1(a) and 1(b) quantify the results presented in Figures 6, 7, and 8 above.

Our national-level time series analysis avoids the potential confounding influences of bank mergers and jurisdictional competition. Thus, as a rough before-and-after test of the prudent investor rule's effect free from such confounding influences, we assess the existence of a structural break in 1997. We chose 1997, which is just a few years after the promulgation of the Restatement [Third] and UPIA, because by that year 37 states, with 71 percent of reported trust assets, had adopted the prudent investor rule.

In the FDIC data, we can also measure how correlations between trust corpus and the S\&P500 change before and after state-by-state adoption of the prudent investor rule. To do so, we examine the data at the state level and run the following difference-in-differences regression:

$$
\begin{gathered}
\text { (2) } \% \Delta \text { Average Trust } \text { Corpus }_{s t}=\alpha+\delta \% \Delta S \& P 500_{t}+\sigma \text { Prudent }_{s t}+ \\
\tau \text { Prudent }_{s t} \mathrm{x} \% \Delta S \& P 500_{t}+\alpha \text { TimeTrend }_{t}+\mu \text { state }_{s}+\varepsilon_{b s t}
\end{gathered}
$$

than preferred shares. But all of these shares are coded as "stock" within the FDIC data. Nonetheless, given the old rule's hostility to equity and emphasis on avoiding risk, the shift from "safe" assets to stock suggested by Figure 2 and found in Schanzenbach and Sitkoff (2007), and the finding below, consistent with Figure 8, that there is no significant relationship between yearly changes in the S\&P 500 and non-stock assets, it appears that stock holdings are the locus of most market risk in the trust data. 
Prudent is a dummy equal to one if the state has adopted the rule. ${ }^{32}$ The variables of interest are $\delta$, $\sigma$ and $\tau: \delta$ indicates the overall correlation between changes in trust corpus and changes in market returns, $\sigma$ indicates whether average trust size grew at a different pace after the prudent investor rule, and $\tau$ indicates whether the rule affected the correlation between changes in trust corpus and changes in the S\&P500. Because the S\&P 500 varies only by year, we use do not use time dummies but instead use a third-order polynomial in time represented by the variable TimeTrend.

Relative to the national-level analysis, the state-level regressions have the advantage of state-by-state identification based on the year in which each state adopted the prudent investor rule. The disadvantage of the state-level regressions is the potential for confounding influences of bank mergers and jurisdictional competition. We verify that the state-level approach is valid by comparing the asset-weighted state-level results to the national results in equation 1(a). If the state-level approach is confounded by mergers and asset movements between states, the coefficient $\delta$ should be different in the state results. We show that the state-level approach gives results (when weighted) similar to the national level results. We do not further disaggregate the analysis to the bank-level. Changes in asset levels at the bank-level are quite noisy, and are driven heavily by mergers and consolidations as well as the termination or creation of individual trusts.

Unlike in our prior analysis of risk tolerance, in our analysis of correlation of returns we do not directly control for jurisdictional competition, as doing so would require several additional interactions with $\% \Delta S \& P 500$, and we lack the power to identify these possible effects separately. Nor can we cut the data, because in our sample timeframe there were no meaningfully negative S\&P 500 years prior to 2001. Instead, we rely on the comparison of state-level with national-level results. We also report results that cut the data in 2009 to exclude any postfinancial crisis data anomalies.

If trustees responded to enactment of the prudent investor rule by taking on more risk, then the sign on $\sigma$ should be positive in the long run, as both the average return and variance of returns should increase. In contrast, the sign on $\tau$ could be either positive or negative. If trustees took on more risk, as is implied by our findings on portfolio allocation, then $\tau$ might be positive, reflecting a stronger correlation between changes in the market and changes in assets.

On the other hand, for at least two reasons, both consistent with the prudent investor rule, $\tau$ could also be negative. First, given the rule's emphasis on diversification, trustees might have invested in a broader range of stocks than those that comprise the S\&P 500 (e.g., mid- and small-cap issues or foreign stocks), reducing the correlation between trust corpus and the S\&P500. ${ }^{33}$

\footnotetext{
${ }^{32}$ In some states, the reform took effect during the year rather than as of January 1, but our FDIC data is as of December 31. We therefore code the year of adoption as the percentage of the year in which the rule was effective. The earliest effective dates for the prudent investor rule and for principal-and-income reform in each state are given in the Appendix Table.

${ }^{33}$ In a related vein, the Beta of bonds declined in the late 1990s, which would also reduce the correlation between trust corpus and the S\&P 500. To exclude the influence of this effect, in some specifications we examine only the stock portion of trust corpus.
} 
Second, after the reform trustees might have more frequently rebalanced trust portfolios. Because we observe total trust corpus only at the end of the calendar year, but rebalancing occurs from time to time throughout the year, the muting effect of rebalancing would be especially strong when, as in the 1990s, the market exhibited a consistent and unusual upward trajectory so rebalancing would have entailed selling into a rising market. In the period under study, moreover, full calendar-year S\&P 500 returns were highly correlated with returns in shorter calendar-year periods. Between 1986 and 2012, the correlation between the calendar-year return and the January-to-September return was 0.89 , and the correlation between the calendaryear return and January-to-June return was 0.79 . As such, increased rebalancing at any point in the period under study would mute the correlation between changes in year-end observed trust corpus and yearly changes in the S\&P 500.

Our data, which is by asset class, do not allow us to test whether trust portfolios became more diversified after the reform. However, we can assess the rebalancing hypothesis in two ways. First, we allow for an asymmetric trustee response to positive and negative market returns as suggested by Figure 8 . An asymmetric response is consistent with rebalancing by selling equities in up markets to keep market risk exposure below a certain threshold while not purchasing additional stock during down markets. A similar asymmetry has been observed in the management of university endowments, specifically different management in up versus down markets (Brown et al. 2014). Second, we reassess the correlation between trust corpus and the market by substituting S\&P 500 returns for January through September instead of the full-year returns specified in Equation 2. Because we observe trust corpus only at year end, a stronger increase in correlation with the first nine months of S\&P 500 returns relative to fullyear returns would suggest a tempering of exposure to market risk by rebalancing from time to time across the year.

\section{Results}

Table 5 presents our estimates of equations 1(a) and (b), which assess relationship at the national level between the S\&P 500, our independent variable, and trust corpus, stock holdings, non-stock holdings, and fiduciary fees, our dependent variables. The numbers in the first row are interpreted as the effect of a one percentage point change in the S\&P 500 on the change in trust variable at issue (i.e., trust corpus, stock holdings, non-stock holdings, and fiduciary fees). "Total Assets" and "Total Fees" results are based on the percentage aggregate yearly change. "Average Account” and “Average Fees” results are based on a division of the yearly aggregate by the number of accounts and the number of returns respectively. The FDIC data for trust assets span 1986 through 2012 and for stock and non-stock holdings span 1986 through 2008. The results using fiduciary fees from the IRS data span the years 2000 through 2011 (because we measure yearly changes, we exclude 1997).

The estimated effect of a one percent change in the S\&P 500 on the change in trust corpus is 0.49 percent for total corpus and 0.53 percent for average account size. These results imply that a one percent change in the S\&P 500 leads to roughly a 0.5 percent change in total trust assets. The fiduciary fees results suggest that a one percent change in the S\&P 500 leads to about a 0.4 percent change in trust assets, a somewhat smaller result that is consistent with such fees being computed on a graduated scale. Accordingly, we conclude that the two data sets yield similar results that are in line with our reading of Figures 6, 7, and 8. Durbin-Watson and Bruesch-Pagan tests reject first-order autocorrelation for all specifications, as is to be expected in a financial times series taking first differences on returns on assets. 
In middle columns of Table 5, we examine stock holdings and non-stock holdings separately. The estimated effect of a one percent change in the S\&P 500 on stock holdings is 0.82 for total corpus and 0.87 for average account size. In other words, a one percent change in the S\&P 500 leads to a 0.82 or 0.87 percent change in stock holdings. The R-square for these specifications is 0.9 , which means that almost all of the changes in stock holdings can be explained by changes in the S\&P 500. The estimated effect of a one percentage point change in the S\&P 500 on non-stock holdings is only 0.09 for both total corpus and average account size, and the $\mathrm{R}$-square for these specifications is 0.07 and 0.10 respectively. In sum, trust stock holdings are strongly correlated with the market and non-stock holdings are not. Overall, these results are consistent with the notion that stock holdings closely proxy for movement out on the risk-return curve, and that non-stock portfolio is little exposed to market risk.

In the bottom half of Table 5, as a rough before-and-after test of the effect of the prudent investor rule, we allow for a structural break in 1997 in our analysis of the FDIC Data (the IRS data postdates 1997). The correlation between S\&P 500 returns and changes in trust assets in the first period fell from 0.60 to 0.42 and from 0.58 to 0.50 . These coefficient estimates imply a reduction in correlation between the market and trust corpus after the rule, albeit the coefficients are not statistically different from each other, whether with a one-tail or two-tail test. In all events, we can say with statistical confidence that there was no observable increase in correlation after the proliferation of the rule by 1997 . We believe that this finding of no increase in correlation with the market in spite of the substantial increase in stockholdings reflects increased rebalancing after the rule.

If trustees rebalance in rising markets to restrain exposure to market risk in accordance with the "ongoing duty to monitor investments and to make portfolio adjustments if and as appropriate" (Restatement [Third], sec. 90, comment e[1]), then the percent increase in stock holdings from the prior year will be less than the percent increase in the S\&P 500 from the prior year. Figure 8, which shows that the relationship between changes in the S\&P 500 and changes in stock holdings weakens after 1997, is thus suggestive of rebalancing. This interpretation of Figure 8 is supported by the more formal analysis in Table 5. Prior to 1997, a one percent change in the S\&P 500 was associated with more than a 0.95 percent change in percent stock holdings. After 1997, by contrast, the coefficient falls to 0.73 (total corpus) and 0.81 (average account size).

The national time-series approach of Table 5 avoids the potential confounding influences of bank mergers and jurisdictional competition, but it relies on a crude before-and-after test to identify the effect of the prudent investor rule. To examine more precisely the effect of the rule on the correlation between the change in trust assets and the change in the S\&P 500, Table 6 reports results at the state and bank level based on Equation 2. Moreover, to assess our rebalancing hypothesis, Table 6 also allows for asymmetric responses among trustees to positive and negative returns. Columns 1 through 7 report results taking the percent change in average account size at the state level as the dependent variable. Column 8 examines percent in average stock holdings only. Columns 9 and 10 take log average account size as the dependent variable and log S\&P 500 as the independent variable at the state (column 9) and bank (column 10) levels.

Column 1 of Table 6 reports the result of a simple regression of $\% \Delta S \& P 500$ on $\% \Delta$ Average Account. The coefficient on $\% \triangle S \& P 500$ is 0.5 , which implies that a one percent increase in the S\&P 500 yields a 0.5 percent increase in average account size. Including state fixed effects and a cubic time trend in column 2 yields a similar estimate of 0.54 . These state- 
level results are nearly identical to the national-level results of Table 5, which suggests that noise from bank mergers and jurisdictional competition have not substantially affected the state-level analysis.

Column 3 adds Prudent Investor, a dummy variable for a state's adoption of the prudent investor rule, and its interaction with $\% \Delta$ Average Account. Column 4 repeats this specification but uses $\% \Delta$ Average Account Stockholdings as the dependent variable. In both columns, coefficients on Prudent and the interaction between Prudent and \% $\Delta$ Average Account are small and not statistically significant, suggesting that there was no change in either average account sizes or correlations between trust corpus and the market after the adoption of the Prudent Investor Rule for either trust corpus in general or stockholdings specifically. ${ }^{34}$

Across specifications, the coefficient on Prudent is always positive, but it is only statistically significant in specifications in which allow for asymmetric responses to positive and negative market returns. Moreover, it is not significant in column 7, which is the specification with state-specific time trends. Given the inconsistency in the significance of the Prudent coefficient, we do not emphasize this result.

Column 5 allows for asymmetric correlations between positive and negative returns across the entire period under study. The coefficient on positive returns is 0.44 and on negative returns is 0.69 . The $\mathrm{p}$-value on a one-tail test finds that the correlation with negative returns is higher than those of positive returns at the 0.029 level. Accordingly, changes in average account size are more strongly correlated with the S\&P 500 in down markets than up markets. There is a caveat, however, to the findings regarding negative returns. There were only two negative prior to 2000 to 2002, in 1990 and 1994, and these were very small declines. Because most states had adopted the rule by 2000 , the interaction term relies on very few changes for identification, so we decline to interpret it.

The remaining columns report regressions interacting the Prudent dummy separately with S\&P 500 positive and negative returns, which allows us to identify whether those correlations changed after a state adopted the rule. The results in column 6 suggest that enactment of the prudent investor rule decreased the correlation between trust assets and positive returns and increased the correlation between negative S\&P 500 returns and trust assets. In other words, positive market returns are less correlated with changes in average account size, and negative market returns are more correlated, after the reform. This result is consistent with the asymmetric rebalancing hypothesis.

Column 7 includes state-specific trends and the interaction results are little changed, though the coefficient on Prudent is reduced by half and is no longer significant. Column 8 considers only the change in stock assets, which are only available prior to 2009. Again, $\% \Delta S \& P 500>0 *$ Prudent is negative (p-value .049) and $\% \triangle S \& P 500<0 *$ Prudent is strongly positive ( $\mathrm{p}$-value $<.01$ ). Moreover, the coefficient on $\% \triangle S \& P 500<0 *$ Prudent is almost exactly one, and the main effect is tiny, implying a one-to-one loss in the value of stock holdings relative to the S\&P500 in down years after adoption of the rule.

Table 7 presents the results of our reassessment of the correlation between changes in trust corpus and changes in the market by substituting January-to-September market returns as our measure of market risk in equation 2 for the full calendar-year returns reported in Table 6.

\footnotetext{
${ }^{34}$ As before, this state-level result is comparable to the national-level before-and-after finding in Table 5.
} 
If in fact trustees tempered exposure to market risk in up years by rebalancing from time to time, then our year-end observation of changes in trust corpus should be more correlated with January-to-September market returns than the full-year returns. ${ }^{35}$ In columns 1 and 2 of Table 7, we estimate Equation 2 for trust corpus and trust stockholdings respectively. These specifications are thus comparable to columns 3 and 4 in Table 6 , but with $\% \Delta S \& P 500$ measured from January to September instead of January to December. In contrast to Table 6, in which we observed no statistically significant effect from enactment of the prudent investor rule, in Table 7 we observe a significant and positive effect, especially in the stockholdings only specification (column 2), in which the coefficient is 0.32 and is highly significant.

In columns 3 and 4 of Table 7, we allow for an asymmetric correlation between positive and negative market returns. These specifications are thus comparable to columns 7 and 8 in Table 6. Unlike in Table 6, however, in Table 7 we find no evidence of a decrease in correlation with positive returns. We attribute this result to the closer alignment of trust corpus with January-to-September market returns on account of rebalancing across the year.

\section{Discussion}

Our findings on the correlation between trust corpus and the S\&P500 before and after the prudent investor rule suggest that, although stockholdings increased after the rule, trust corpus did not become more correlated with the market. To the contrary, our rough before-andafter estimates at the national level indicate that aggregate trust corpus remained roughly as correlated with the market as it had been across the decade or so prior to the rule.

Our more nuanced state-level analysis exploits variation in the timing of state statutory adoptions of the rule. Our initial finding of no change in correlation between trust corpus and the market is similar to that in the national analysis. However, when we allow for an asymmetric trustee response to positive and negative market returns, and when we examine January-toSeptember rather than full-year market returns, we find evidence of increased portfolio rebalancing in accordance with the rule's imposition of an "ongoing duty to monitor investments and to make portfolio adjustments if and as appropriate" (Restatement [Third], sec. 90, comment $\mathrm{e}[1])$.

For two reasons, we conclude that more frequent rebalancing muted what would have otherwise been an increased correlation. First, after adoption of the rule, the correlation between trust corpus and full-year market returns decreases in positive markets. This effect, which is generally precisely estimated, implies an increase in rebalancing in up markets after the rule. By contrast, we observe no change after the rule in the correlation between trust corpus and negative markets. This finding implies that after the rule trustees were no more or less likely to acquire additional stockholdings in down markets than they were before the rule. ${ }^{36}$ Second, after adoption of the rule, changes in trust corpus became more correlated with January-toSeptember market returns and less correlated with full-year returns. Because rebalancing occurs from time to time across the year, but we observe trust corpus only at year end, this result is consistent with rebalancing activity in between our year-end observations of trust corpus.

\footnotetext{
${ }^{35}$ Unreported regressions using January-to-June returns yielded similar point estimates, albeit they were less precisely estimated.

${ }^{36}$ That there is an asymmetry in rebalancing in up versus down markets is particularly evident in Column 8 of Table 6, which considers the correlation between yearly changes in stockholdings (rather than corpus) and the market. The estimate in that specification for negative market returns is almost exactly one, whereas the positive correlation is significantly less than one.
} 
The observed asymmetry in rebalancing in up versus down markets could reflect an irrational behavioral bias against stock investment in a down market. There are, however, at least two other explanations that are consistent with rational risk management by trustees. First, most of the down years in our sample were quite dramatic, including 2001, 2002, and 2008, and coincided with significant recessions. The overall wealth of the beneficiaries, and so their risk tolerances, may well have declined in those years, warranting a lowering in the bottom range of the trust's target equity allocation. Second, because trusts commonly provide for periodic distributions to one or more beneficiaries, and because these distributions must be continued even in the event of a diminished corpus, such trusts may be constrained in their ability to reallocate toward stock following a large loss.

Our interpretation of the results as implying increased rebalancing after the rule reconciles the observed increase in stockholdings, and so increased exposure to market risk, with our finding of no increase in correlation between trust corpus and the market. We emphasize that our results do not demonstrate that trusts were not exposed to additional market risk after the rule. Instead, our results imply that the increased market risk exposure that follows from additional stockholdings was attentively managed in accordance with the continuing responsibility under the rule to make ongoing portfolio adjustments. In the words of the Restatement, "risk management by a trustee requires that careful attention be given to the particular trust's ... tolerance for volatility” (Restatement [Third], sec. 90, comment e[1]).

An alternative explanation for unchanged correlation after the rule is that, although stock holdings increased, those holdings were better diversified in a broader range of stocks than those that comprise the S\&P 500. Given the limits of our data, we cannot assess these possibilities, which are consistent with prudent risk management under the rule and are not inconsistent with our finding of increase rebalancing. To put the point otherwise, we find strong evidence of increased rebalancing after the rule, which may have coincided also with broader diversification.

\section{Conclusion}

Using data from reports of bank trust holdings and fiduciary income tax returns, this paper evaluated the effect of the prudent investor rule on trustee management of market risk. There are two key conclusions. First, stock holdings and account size are strongly correlated, with the reform having had the greatest effect among banks with mid-sized trust accounts, in which we observe an increase in stockholdings of 3 to 5 percentage points depending on the specification. Second, although stockholdings and so exposure to market risk increased after the reform, trust corpus did not become more correlated with the S\&P 500, likely because after the reform trustees more frequently rebalanced portfolios across the year between our yearly observations.

Although we lack individual account data, the aggregated data on the national, state, and bank levels paint a clear picture of how trust corpus has responded to changes in the market and how portfolio allocation relates to account size. The evidence strongly suggests that market risk exposure has been sensitive to beneficiary risk tolerance and market risk exposure has been managed on an ongoing basis. After enactment of the rule, we observe increased stockholdings and so increased exposure to market risk in more risk tolerant trusts, and increased rebalancing to manage this increase market risk exposure. Accordingly, we conclude that the prudent inves- 
tor rule has been applied as intended, and that recent calls for repeal of the rule, which assume a failure in risk management by trustees, are unsupported by the evidence. 


\section{REFERENCES}

Ascher, Mark L. 2011. The Grantor Trust Rules Should Be Repealed. Iowa Law Review 96:885-940.

Begleiter, Martin D. 1999. Does the Prudent Investor Need the Uniform Prudent Investor Actan Empirical Study of Trust Investment Practices. Maine Law Review 51:27-85.

Brown, Jeffrey R., Stephen G. Dimmock, Jun-Koo Kang, and Scott J. Weisbenner. 2014. How University Endowments Respond to Financial Market Shocks: Evidence and Implications. American Economic Review. 104(3):931-62.

Citibank, N.A. 1977. Attorney's Reference File of Will and Trust Forms. 5th ed. (Revised).

Cooter, Robert, and Bradley J. Freedman. 1991. The Fiduciary Relationship: Its Economic Character and Legal Consequences. New York University Law Review 66:1045-75.

Dagan, Hanoch, and Sharon Hannes. 2014. Managing our Money: The Law of Financial Fiduciaries As a Private Law Institution. In Philosophical Foundations of Fiduciary Law, edited by Andrew S. Gold and Paul B. Miller. Oxford: Oxford University Press.

Del Guercio, Diane. 1996. The Distorting Effect of the Prudent-Man Laws on Institutional Equity Investments. Journal of Financial Economics 40:31-62.

Dukeminier, Jesse, and Robert H. Sitkoff. 2013. Wills, Trusts, and Estates. 9th ed. New York: Aspen Publishers.

Easterbrook, Frank H., and Daniel R. Fischel. 1993. Contract and Fiduciary Duty. Journal of Law \& Economics 36:425-46.

Federal Deposit Insurance Corporation. Statistics on Depository Institutions.

Fi360. 2013. Prudent Practices for Investment Advisors: Defining a Global Fiduciary Standard of Excellence. U.S. ed.

Fishman, James J. 2014. What Went Wrong: Prudent Management of Endowment Funds and Imprudent Endowment Investing Policies. Journal of College and University Law 40(2):199-246.

Getzler, Joshua. 2009. Fiduciary Investment in the Shadow of Financial Crisis: Was Lord Eldon Right? Journal of Equity 3:219-50.

Gordon, Jeffrey N. 1987. The Puzzling Persistence of the Constrained Prudent Man Rule. New York University Law Review 62:52-114.

Hankins, Kristine Watson, Mark J. Flannery, and Mahendrarajah Nimalendran. 2008. The Effect of Fiduciary Standards on Institutions' Preference for Dividend-Paying Stocks. Financial Management 37.4: 647-671.

Hofri-Winogradow, Adam S. 2014. The Stripping of the Trust: From Evolutionary Scripts to Distributive Results. Ohio State Law Journal 75:529-70.

Hofri-Winogradow, Adam S. Forthcoming. The Stripping of the Trust: A Study in Legal Evolution. University of Toronto Law Journal 65:1-47.

Internal Revenue Service. Income from Trusts and Estates Statistics.

Kiziah, Trent S. 2011. Remaining Heterogeneity in Trust Investment Law After Twenty-Five Years of Reform. ACTEC Law Journal 37:317-64.

Langbein, John H. 1995. The Contractarian Basis of the Law of Trusts. Yale Law Journal 105:625-75.

Langbein, John H. 1996. The Uniform Prudent Investor Act and the Future of Trust Investing. Iowa Law Review 81:641-69.

Langbein, John H. 2004. Mandatory Rules in the Law of Trusts. Northwestern University Law Review 98:1105-28.

Langbein, John H. 2004. The Rise of the Management Trust. Trusts \& Estates, October 1.

Langbein, John H., and Richard A. Posner. 1976. Market Funds and Trust-Investment Law. American Bar Foundation Research Journal 1976:1-34. 
Langbein, John H., and Richard A. Posner. 1977. Market Funds and Trust-Investment Law: II. American Bar Foundation Research Journal 1977:1-43.

Longstreth, Bevis. 1986. Modern Investment Management and the Prudent Man Rule. New York: Oxford University Press.

McLaughlin, Susan. 1995. The Impact of Interstate Banking and Branching Reform: Evidence from the States. Federal Reserve Bank of New York, Current Issues in Economics and Finance 1(2):1-6.

New York State Bankers Association. Temporary State Commission on the Modernization, Revision, and Simplification of the Law of Estates. 1964. Report No. 6.12A: The Prudent Man Rule for Fiduciary Investments.

Rachlinski, Jeffrey J. 2000. Heuristics and Biases in the Courts: Ignorance or Adaptation? Oregon Law Review 79:61-102.

Restatement (Second) of Trusts. 1959.

Restatement (Third) of Trusts. 1992.

Schanzenbach, Max M., and Robert H. Sitkoff. 2007. Did Reform of Prudent Trust Investment Laws Change Trust Portfolio Allocation? Journal of Law \& Economics 50:681-709.

Scoles, Eugene F. 2002. Choice of Law in Trusts: Uniform Trust Code, Sections 107 and 403. Missouri Law Review 67(2):213-40.

Shattuck, Mayo A. 1951. The Development of the Prudent Man Rule for Fiduciary Investment in the United States in the Twentieth Century. Ohio State Law Journal 12:491-521.

Sherman, Jeffrey G. 1998. All You Really Need to Know About Subchapter J You Learned From this Article. Missouri Law Review 63(1):1-49.

Sitkoff, Robert H. 2004. An Agency Costs Theory of Trust Law. Cornell Law Review 89(3):621-84.

Sitkoff, Robert H. 2011. The Economic Structure of Fiduciary Law. Boston University Law Review 91:1039-49.

Sitkoff, Robert H. 2013. Trust Law As Fiduciary Governance Plus Asset Partitioning. Pp. 42853 in The Worlds of the Trust, edited by Lionel Smith. New York: Cambridge University Press.

Sitkoff, Robert H. 2014a. An Economic Theory of Fiduciary Law. Pp. 197-208 in Philosophical Foundations of Fiduciary Law, edited by Andrew S. Gold and Paul B. Miller. New York: Oxford University Press.

Sitkoff, Robert H. 2014b. The Fiduciary Obligations of Financial Advisors under the Law of Agency. Journal of Financial Planning 27:42-49.

Sitkoff, Robert H., and Max M. Schanzenbach. 2005. Jurisdictional Competition for Trust Funds: An Empirical Analysis of Perpetuities and Taxes. Yale Law Journal 115:356437.

Sterk, Stewart E. 2003. Jurisdictional Competition to Abolish the Rule Against Perpetuities: R.I.P. for the R.A.P. Cardozo Law Review 24:2097-118.

Sterk, Stewart E. 2010. Rethinking Trust Law Reform: How Prudent Is Modern Prudent Investor Doctrine? Cornell Law Review 95:851-904.

Twain, Mark. 1899. Pudd'nhead Wilson: And Those Extraordinary Twins. New York and London: Harper \& Brothers. 
Figure 1: Average Account Size \& Number of Accounts (FDIC Data)

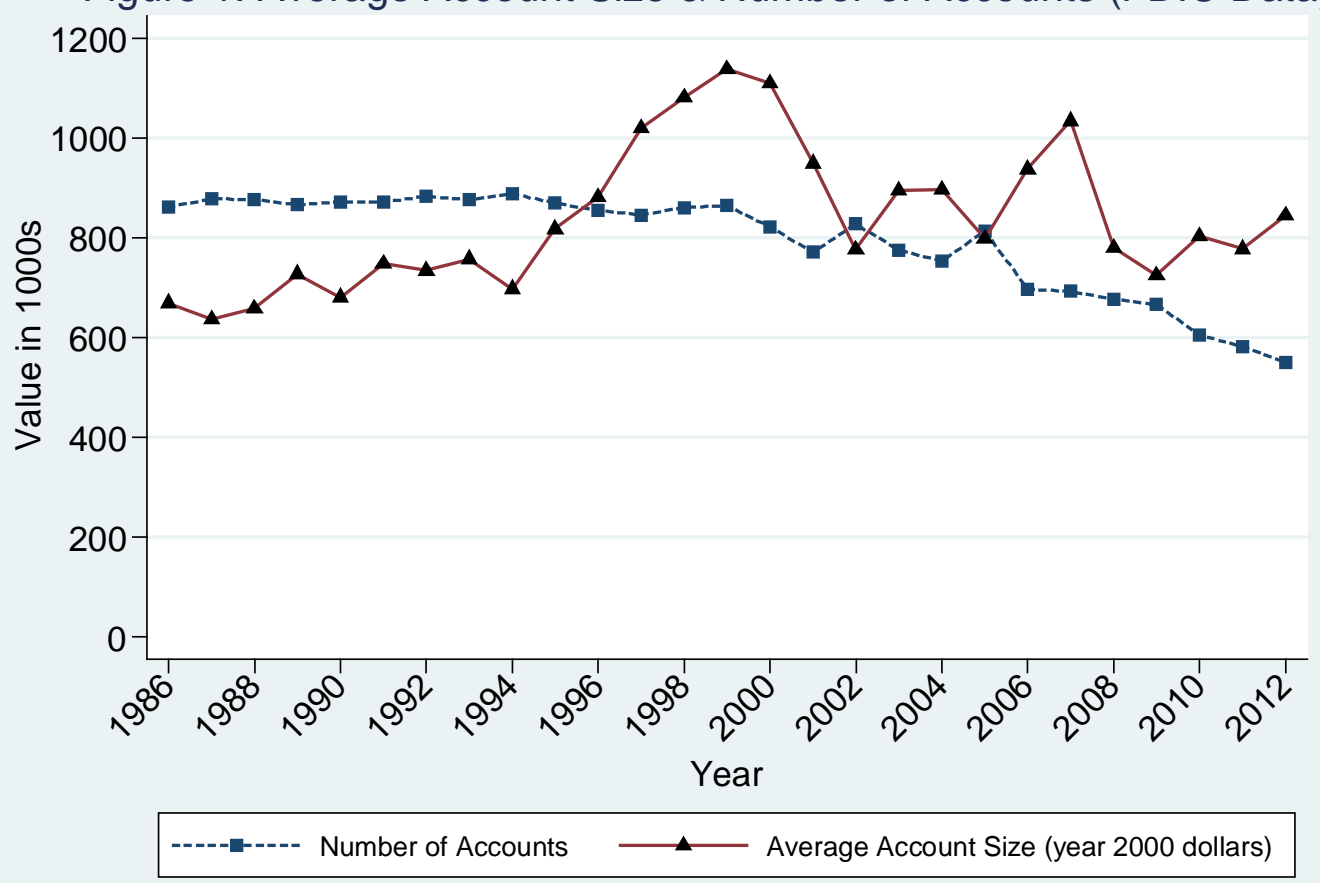

Figure 2: Personal Trust Assets in Stock and Safe Assets

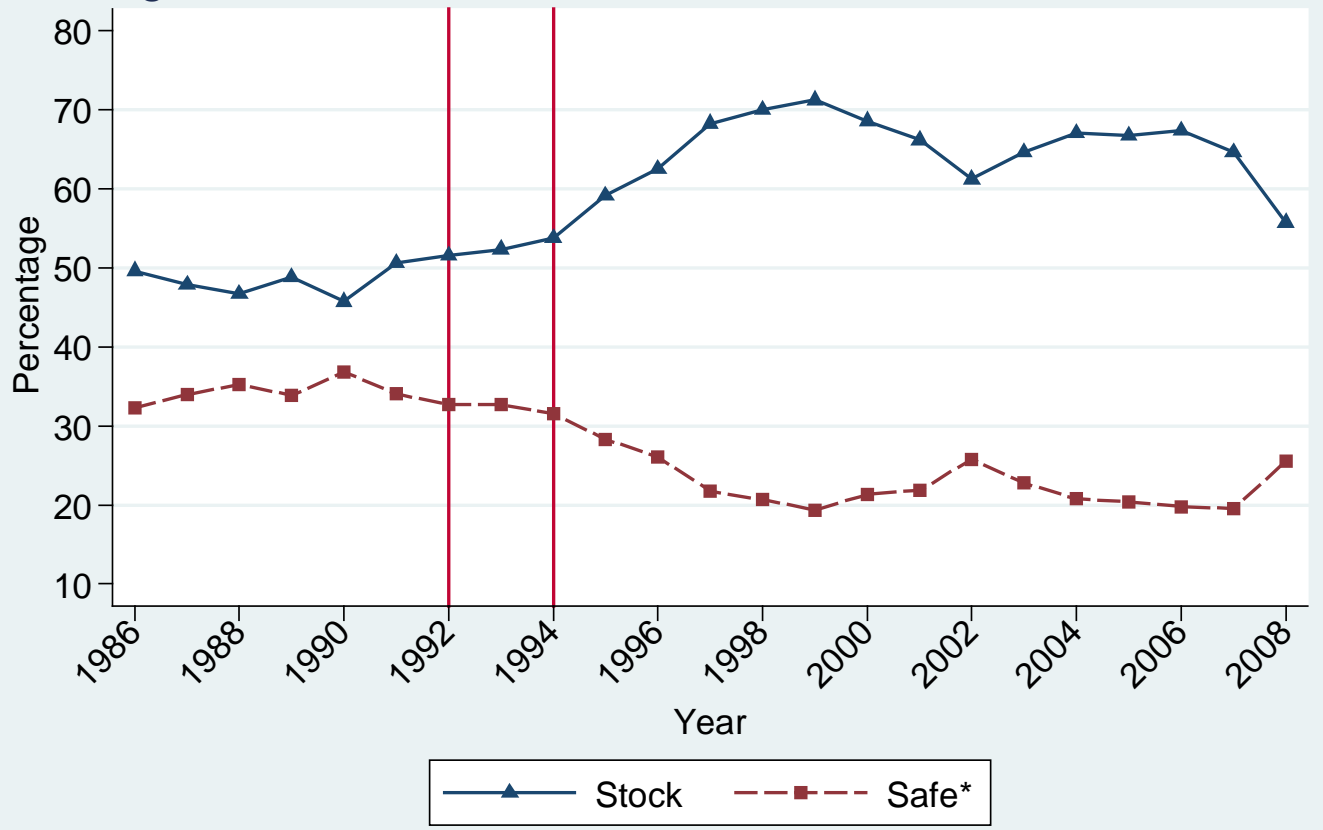

*Safe assets are government bonds, insured deposits, and money market funds 


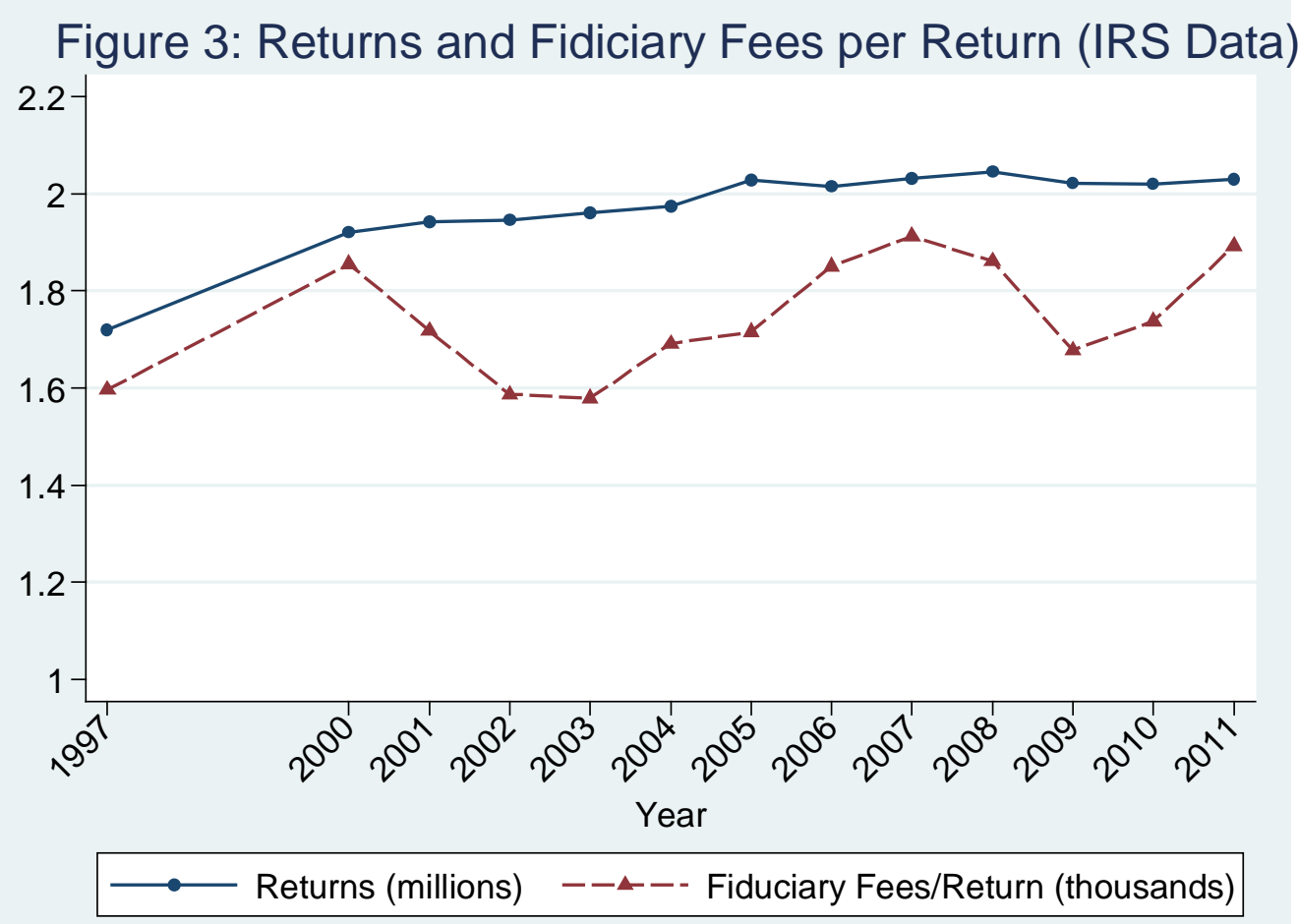

Figure 4: Stock Holdings by Bank Average Account Size

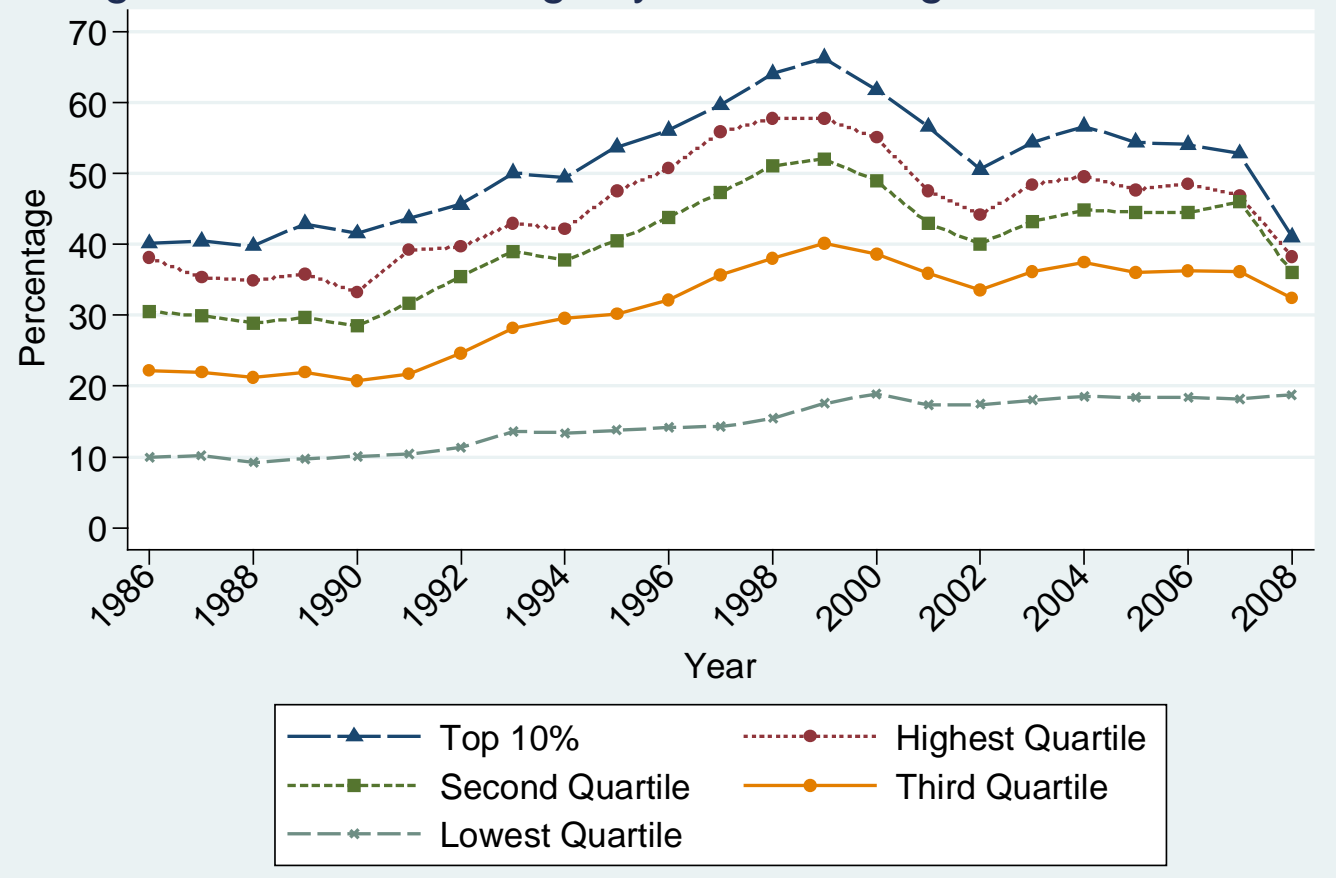


Figure 5: Percent Stock by Log Average Account (Lowess Curves)

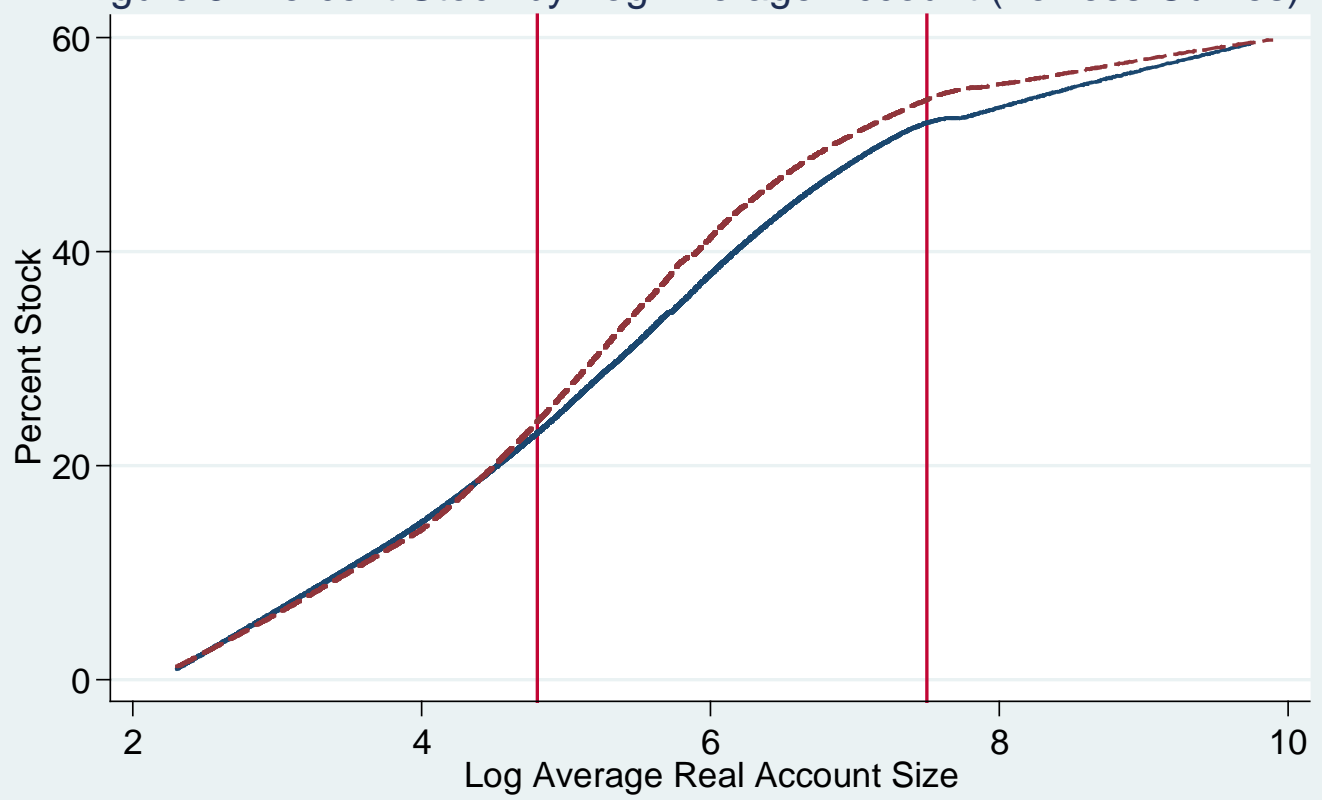

Old Prudent Man Rule/Legal List---- New Prudent Investor Rulle

Figure 6: Trust Corpus and S\&P 500 (FDIC Data)

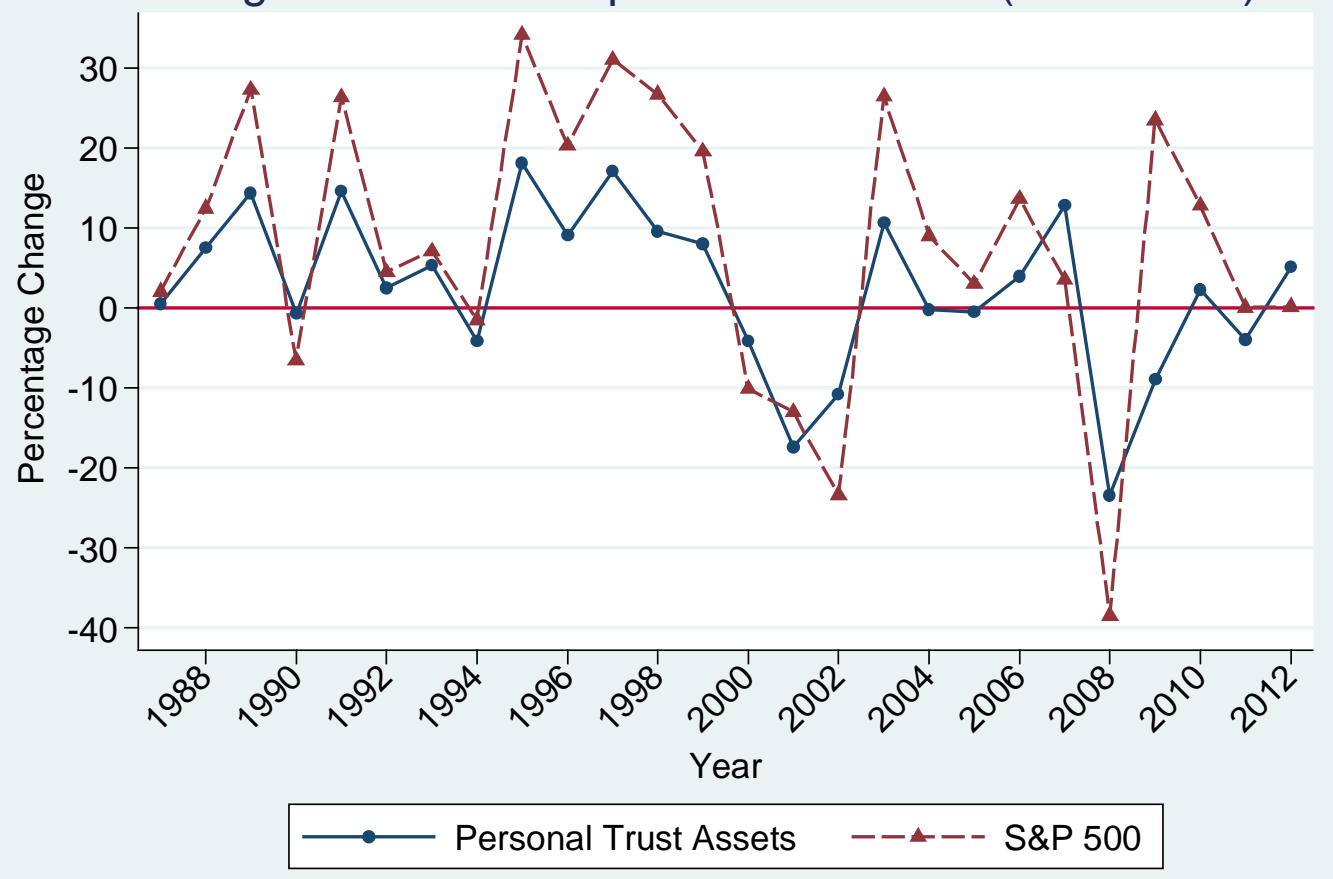




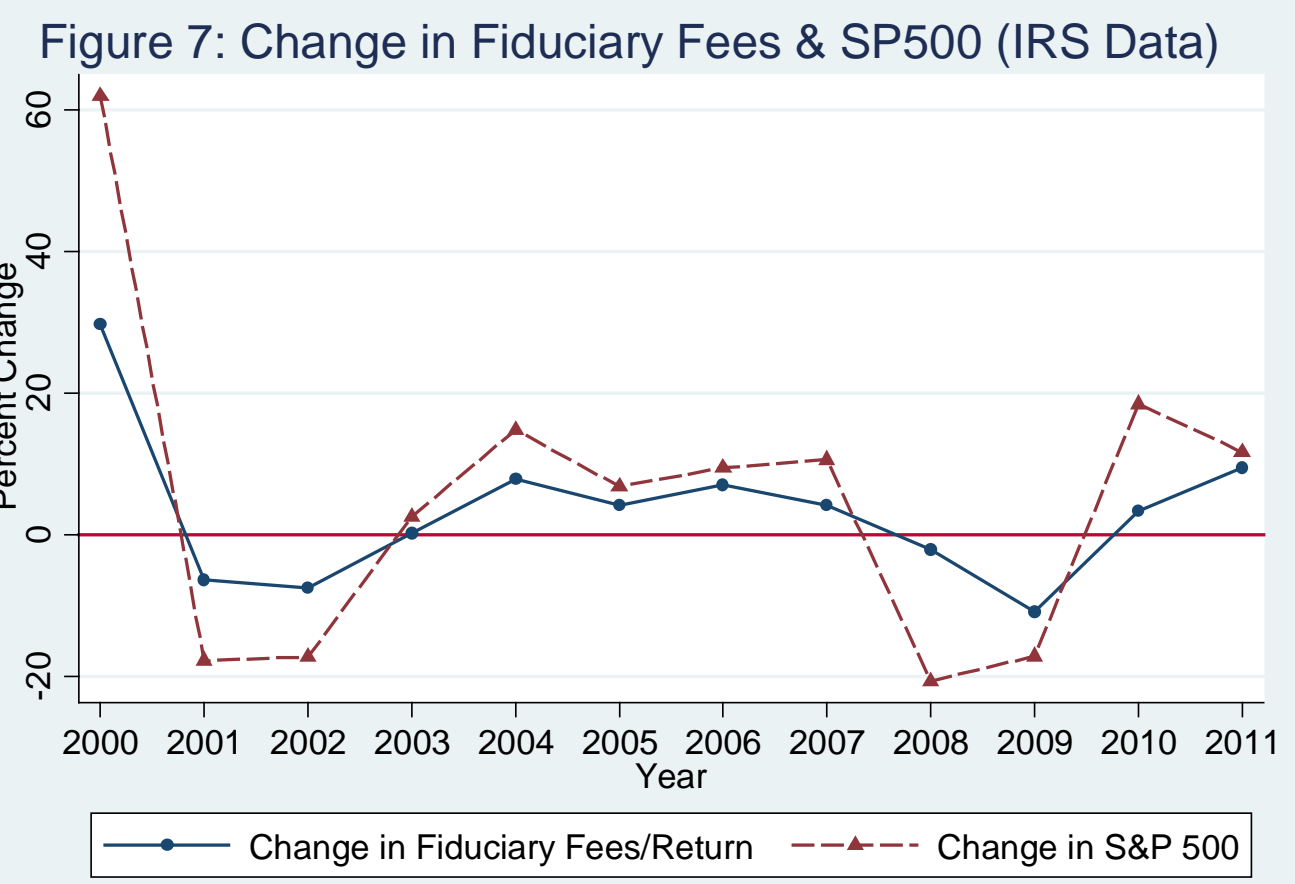

Year 2000 based on change from 1997

Figure 8: Non-Stock Assets, Stock, and S\&P 500 (FDIC Data)

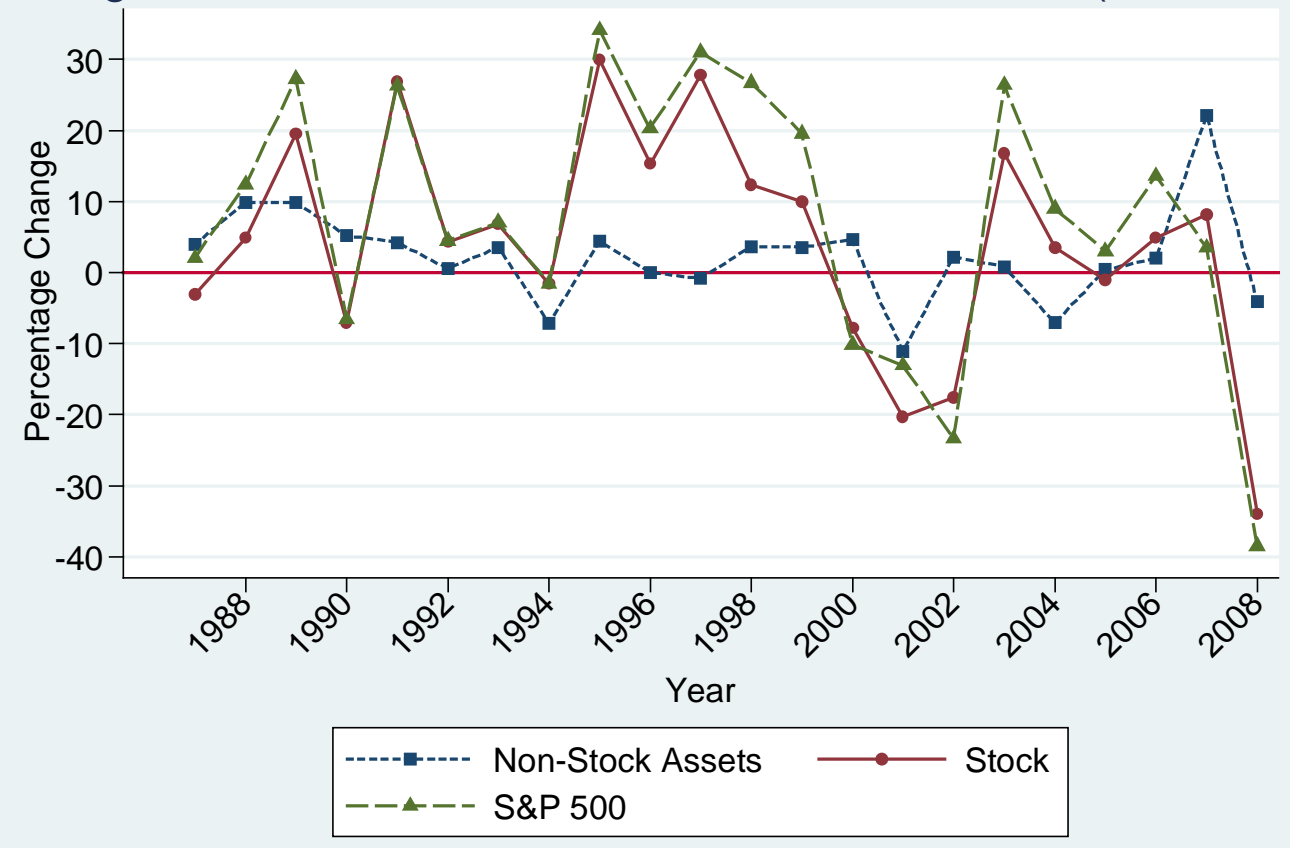


Table 1: Summary Statistics

Assets and Stock Holdings in FDIC Data (Yearly Averages)

\begin{tabular}{lcccc}
\hline & All Years & $1986-1994$ & $1995-2000$ & $2001-2012$ \\
\hline Asset Level (billions) & 810.9 & 583.1 & $1,020.2$ & 877.0 \\
& $(206.5)$ & $(826.7)$ & $(164.0)$ & $(103.7)$ \\
Number of Accounts & 792.4 & 851.3 & 852.5 & 700.8 \\
(thousands) & $(102.8)$ & $(818.0)$ & $(175.4)$ & $(902.8)$ \\
Average Account Size & $1,052.1$ & 883.0 & $1,261.8$ & $1,072.3$ \\
(thousands) & $(182.5)$ & $(142.6)$ & $(175.3)$ & $(115.3)$ \\
Percent Stock & $59.1 \%{ }^{*}$ & $49.6 \%$ & $66.6 \%$ & $64.2 \%{ }^{*}$ \\
\hline Dollar amounts are in year 2010 dollars. ${ }^{*}$ Computed through 2008.
\end{tabular}

Dollar amounts are in year 2010 dollars. ${ }^{*}$ Computed through 2008.

Average Account/Fiduciary Fees

FDIC Data Average $\quad$ Fiduciary Fee per

Account Size (1000s) Return (IRS Data)

\begin{tabular}{|c|c|c|c|}
\hline Overall Average & $\begin{array}{c}\text { State Level } \\
875.6 \\
(621.4)\end{array}$ & $\begin{array}{c}\text { Bank Level } \\
607.1 \\
(3,927)\end{array}$ & $\begin{array}{c}\text { State Level } \\
1,461 \\
(1,653)\end{array}$ \\
\hline 90th Percentile & 1,442 & 945 & 2,483 \\
\hline 75th Percentile & 1,047 & 568.5 & 1,646 \\
\hline 50th Percentile & 745.9 & 340.3 & 1,161 \\
\hline 25th Percentile & 528.6 & 163.9 & 804 \\
\hline $\mathrm{N}$ & 1,347 & 57,841 & 650 \\
\hline
\end{tabular}


Table 2: Quantile Regressions

\begin{tabular}{|c|c|c|c|c|c|c|c|c|}
\hline \multirow{3}{*}{$\begin{array}{l} \\
\text { Log S\&P } 500 \\
\text { (state level) }\end{array}$} & \multicolumn{4}{|c|}{ Log Average Account (FDIC Data) } & \multicolumn{4}{|c|}{ Log Fiduciary Fees per Return (IRS Da- } \\
\hline & OLS & $25^{\text {th }}$ & $50^{\text {th }}$ & $75^{\text {th }}$ & OLS & $25^{\text {th }}$ & $50^{t h}$ & $75^{\text {th }}$ \\
\hline & $\begin{array}{c}0.367 * * \\
(0.0460)\end{array}$ & $\begin{array}{c}\text { Perc. } \\
0.260 * * \\
(0.0872)\end{array}$ & $\begin{array}{c}\text { Perc. } \\
0.365^{* *} \\
(0.0699)\end{array}$ & $\begin{array}{c}\text { Perc. } \\
0.406^{* *} \\
(0.0787)\end{array}$ & $\begin{array}{l}0.349 * * \\
(0.0357)\end{array}$ & $\begin{array}{c}\text { Perc. } \\
0.242^{* *} \\
(0.0630)\end{array}$ & $\begin{array}{c}\text { Perc. } \\
0.285^{* *} \\
(0.0875)\end{array}$ & $\begin{array}{c}\text { Perc. } \\
0.352^{* *} \\
(0.0900)\end{array}$ \\
\hline $\begin{array}{l}\text { Log S\&P } 500 \\
\text { (Bank level) }\end{array}$ & $\begin{array}{c}0.123 * * \\
(0.034)\end{array}$ & $\begin{array}{l}0.0993 * \\
(0.0434)\end{array}$ & $\begin{array}{l}0.196 * * \\
(0.0289)\end{array}$ & $\begin{array}{l}0.250 * * \\
(0.0278)\end{array}$ & & & & \\
\hline
\end{tabular}

**sig at $<0.01$ level; standard errors clustered by state; $\mathrm{N}=1,347$ for FDIC state data; $\mathrm{N}=57,841$ and $\mathrm{N}=650$ for IRS data. All regressions include a cubic time trend and are unweighted. 
Table 3: Percentage Stock Holdings by Account Size (Bank-Level)

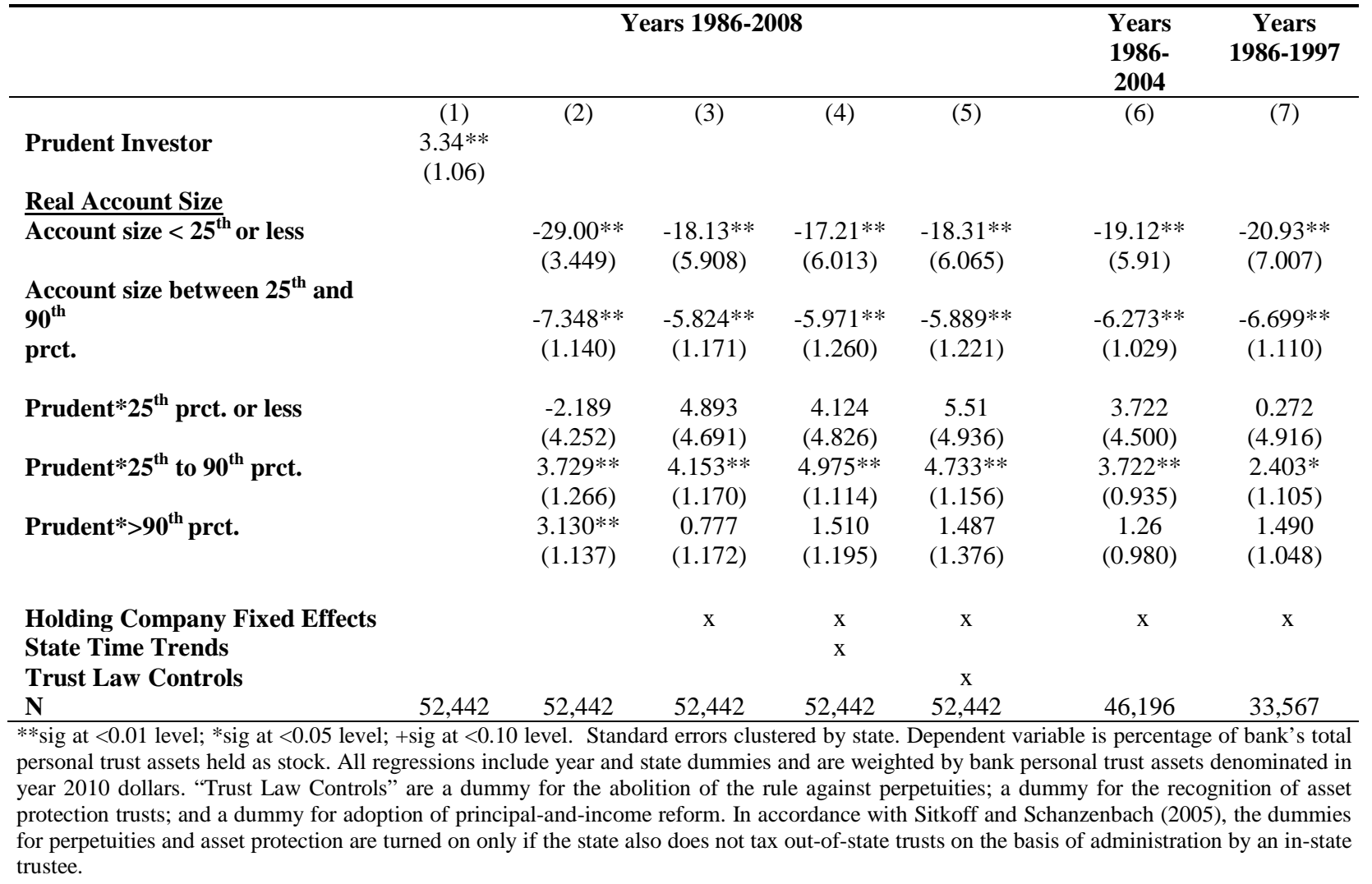


Table 4: Percentage Stock Holdings Account size between 25th and 90th Percentiles (Leads and Lags)

\begin{tabular}{lcccccc}
\hline & \multicolumn{2}{c}{ Years 1986-2008 } & \multicolumn{2}{c}{ Years 1986-2004 } & \multicolumn{2}{c}{ Years 1986-1997 } \\
\hline \multirow{3}{*}{ PIR -5 years or less } & $(1)$ & $(2)$ & $(3)$ & $(4)$ & $(5)$ & $(6)$ \\
& & -1.012 & & -0.756 & & -0.0609 \\
PIR -3 to -4 years & & $(0.710)$ & & $(0.694)$ & & $(0.775)$ \\
& & -1.442 & & -0.776 & & 0.649 \\
PIR -1 to -2 & & $(1.763)$ & & $(1.436)$ & & $(1.531)$ \\
& & & & & & \\
PIR year & $1.356+$ & 0.631 & $1.00+$ & 0.544 & 1.084 & 0.773 \\
& $(0.701)$ & $(0.693)$ & $(0.630)$ & $(0.681)$ & $(0.753)$ & $(0.577)$ \\
PIR + 1 or 2 years & $1.938+$ & 1.231 & $1.588+$ & 1.140 & 1.421 & 0.932 \\
& $(0.990)$ & $(1.063)$ & $(0.819)$ & $(0.944)$ & $(1.016)$ & $(0.845)$ \\
PIR + 3 or 4 years & $4.021^{* *}$ & $3.377^{* *}$ & $3.606^{* *}$ & $3.182^{* *}$ & 1.759 & 1.027 \\
& $(1.195)$ & $(1.236)$ & $(1.173)$ & $(1.115)$ & $(1.581)$ & $(1.490)$ \\
PIR + 5 years or more & $6.071^{* *}$ & $5.557^{*}$ & $4.597^{* *}$ & $4.253^{* *}$ & $2.824+$ & 1.729 \\
& $(1.743)$ & $(2.100)$ & $(1.091)$ & $(1.247)$ & $(1.704)$ & $(1.706)$ \\
& & & & & & 33,567 \\
\hline
\end{tabular}

**sig at $<0.01$ level; *sig at $<0.05$ level; +sig at $<0.10$ level. Standard errors clustered by state. Dependent variable is percentage of bank's total personal trust assets held as stock. All regressions include year and state dummies and are weighted by bank personal trust assets denominated in year 2010 dollars. Leads and lags interactions were included for banks in the 90th plus and in the 25th or less percentiles as before, but none of the coefficients were significant at conventional levels. 
Table 5: Relationship between $\% \Delta$ Trust Assets and $\% \Delta$ S\&P500 (National Level)

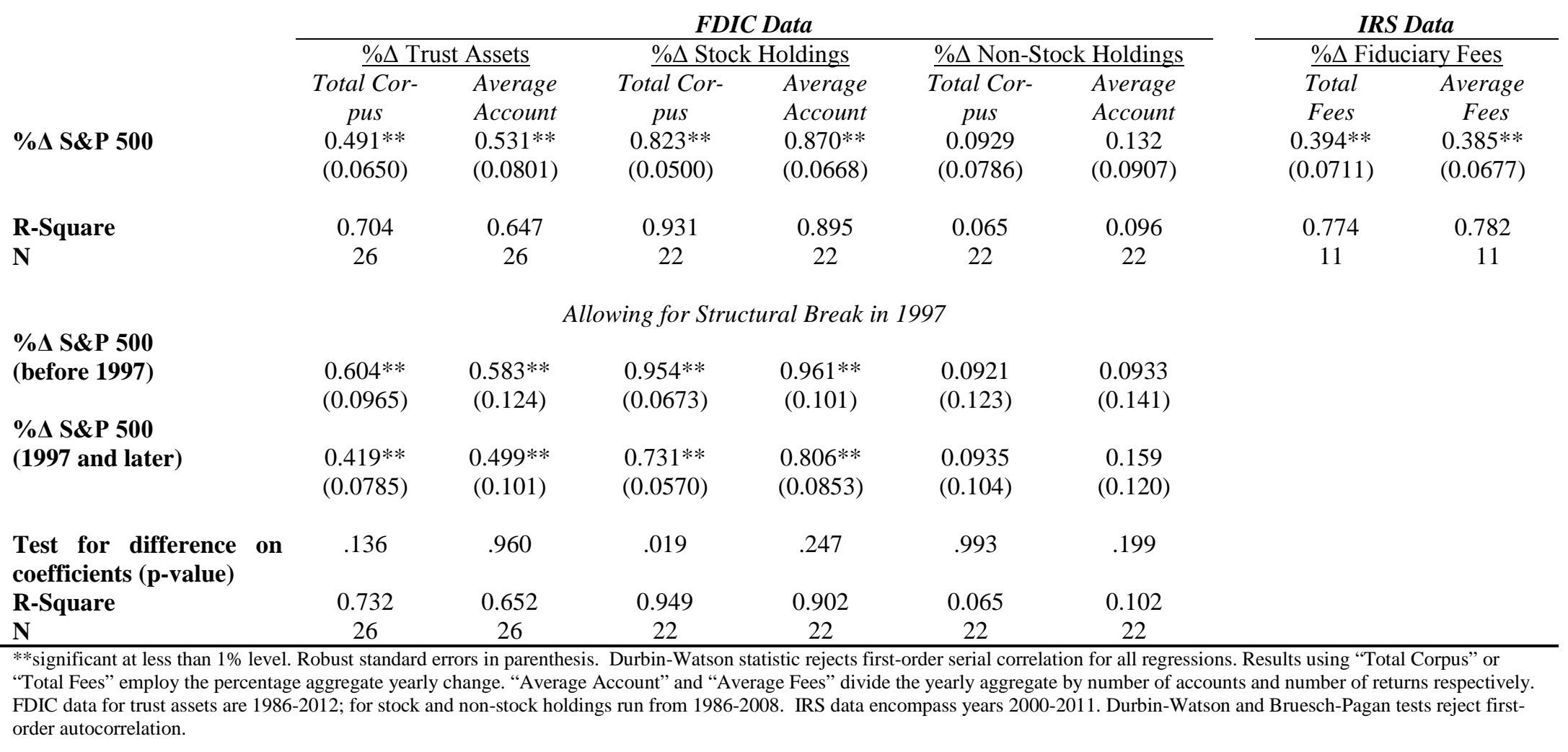


Table 6: Relationship between \%Average Account Assets, \% $\%$ S\&P500, and the Prudent Investor Rule

\begin{tabular}{|c|c|c|c|c|c|c|c|c|}
\hline & \multicolumn{8}{|c|}{$\% \Delta$ Average Account } \\
\hline & $(1)$ & $(2)$ & (3) & $(4)$ & (5) & (6) & $(7)$ & $(8)$ \\
\hline$\% \Delta S \& P 500$ & $\begin{array}{c}0.496^{* *} \\
(0.038)\end{array}$ & $\begin{array}{c}0.541 * * \\
(0.051)\end{array}$ & $\begin{array}{c}0.559 * * \\
(0.033)\end{array}$ & $\begin{array}{c}0.860^{* *} \\
(0.045)\end{array}$ & & & & \\
\hline$\% \Delta S \& P 500>0$ & & & & & $\begin{array}{c}0.444 * * \\
(0.067)\end{array}$ & $\begin{array}{c}0.675^{* *} \\
(0.048)\end{array}$ & $\begin{array}{c}0.571 * * \\
(0.051)\end{array}$ & $\begin{array}{c}0.957 * * \\
(0.061)\end{array}$ \\
\hline$\% \Delta S \& P 500<0$ & & & & & $\begin{array}{c}0.691^{* *} \\
(0.100)\end{array}$ & $\begin{array}{l}-0.396 \\
(0.263)\end{array}$ & $\begin{array}{l}-0.110 \\
(0.251)\end{array}$ & $\begin{array}{l}-0.008 \\
(0.352)\end{array}$ \\
\hline Prudent & & & $\begin{array}{c}2.34 \\
(3.27)\end{array}$ & $\begin{array}{c}3.34 \\
(4.21)\end{array}$ & & $\begin{array}{l}8.78 * * \\
(2.75)\end{array}$ & $\begin{array}{c}4.58 \\
(3.42)\end{array}$ & $\begin{array}{l}8.14 * \\
(3.92)\end{array}$ \\
\hline$\% \Delta S \& P$ 500*Prudent & & & $\begin{array}{l}0.0201 \\
(0.063)\end{array}$ & $\begin{array}{c}.0579 \\
(.0847)\end{array}$ & & & & \\
\hline$\% \Delta S \& P 500>0 *$ Prudent & & & & & & $\begin{array}{c}-0.366 * * \\
(0.111)\end{array}$ & $\begin{array}{c}-0.266^{* *} \\
(0.112)\end{array}$ & $\begin{array}{c}-0.192 * \\
(0.100)\end{array}$ \\
\hline$\% \Delta S \& P 500<0 *$ Prudent & & & & & & $\begin{array}{l}1.16^{* *} \\
(0.260)\end{array}$ & $\begin{array}{c}0.879 * * \\
(0.236)\end{array}$ & $\begin{array}{l}1.09 * * \\
(0.35)\end{array}$ \\
\hline State Fixed Effects & & $\mathrm{x}$ & $\mathrm{x}$ & $\mathrm{x}$ & $\mathrm{x}$ & $\mathrm{x}$ & $\mathrm{x}$ & $\mathrm{x}$ \\
\hline Cubic Time Trend & & $\mathrm{x}$ & $\mathrm{x}$ & $\mathrm{x}$ & $\mathrm{x}$ & $\mathrm{x}$ & $\mathrm{x}$ & $\mathrm{x}$ \\
\hline Stockholdings only & & & & $\mathrm{x}$ & & & & $\mathrm{x}$ \\
\hline State Time Trends & & & & & & & $\mathrm{x}$ & \\
\hline $\mathbf{N}$ & 1,294 & 1,294 & 1,294 & 1,099 & 1,294 & 1,294 & 1,294 & 1,099 \\
\hline
\end{tabular}




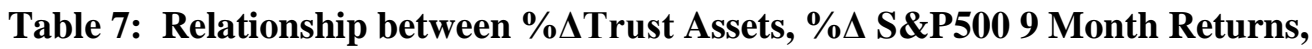
and the Prudent Investor Rule

\begin{tabular}{|c|c|c|c|c|}
\hline & \multicolumn{4}{|c|}{$\% \Delta$ Average Account } \\
\hline & $(1)$ & $(2)$ & (3) & (4) \\
\hline$\% \Delta S \& P 500$ & $\begin{array}{c}0.447 * * \\
(0.067)\end{array}$ & $\begin{array}{c}0.779 * * \\
(0.062)\end{array}$ & & \\
\hline$\% \Delta S \& P 500>0$ & & & $\begin{array}{c}0.523 * * \\
(0.107)\end{array}$ & $\begin{array}{c}0.809 * * \\
(0.099)\end{array}$ \\
\hline$\% \Delta S \& P 500<0$ & & & $\begin{array}{c}0.094 \\
(0.187)\end{array}$ & $\begin{array}{c}0.611^{* *} \\
(0.210)\end{array}$ \\
\hline Prudent & $\begin{array}{c}0.12 \\
(3.20)\end{array}$ & $\begin{array}{c}1.53 \\
(3.95)\end{array}$ & $\begin{array}{c}4.23 \\
(3.00)\end{array}$ & $\begin{array}{l}-0.63 \\
(2.92)\end{array}$ \\
\hline$\% \Delta S \& P 500 *$ Prudent & $\begin{array}{c}0.193+ \\
(0.111)\end{array}$ & $\begin{array}{c}0.318^{* *} \\
(0.131)\end{array}$ & & \\
\hline$\% \Delta S \& P 500>0 *$ Prudent & & & $\begin{array}{c}-0.104 \\
(0.253)\end{array}$ & $\begin{array}{l}0.490+ \\
(0.276)\end{array}$ \\
\hline$\% \Delta S \& P 500<0 *$ Prudent & & & $\begin{array}{c}0.750 * * \\
(0.237)\end{array}$ & $\begin{array}{c}0.334 \\
(0.281)\end{array}$ \\
\hline State Fixed Effects & $\mathbf{x}$ & $\mathrm{x}$ & $\mathrm{x}$ & $\mathrm{x}$ \\
\hline Cubic Time Trend & $\mathbf{x}$ & $\mathrm{x}$ & $\mathrm{x}$ & $\mathrm{x}$ \\
\hline State Time Trends & & & $\mathrm{x}$ & $\mathrm{x}$ \\
\hline Year $<2009$ & & & $\mathrm{x}$ & $\mathrm{x}$ \\
\hline Stockholdings only & & $\mathrm{x}$ & & $\mathrm{x}$ \\
\hline $\mathbf{N}$ & 1,294 & 1,099 & 1,294 & 1,099 \\
\hline
\end{tabular}




\section{Appendix Table ${ }^{37}$}

\begin{tabular}{|lcc|}
\hline Alabama & Prudent Investor Rule & Principal-and-Income Reform \\
\hline Alaska & $5 / 16 / 1989$ & $1 / 1 / 2001$ \\
\hline Arizona & $5 / 23 / 1998$ & $9 / 1 / 2003$ \\
\hline Arkansas & $7 / 20 / 1996$ & $1 / 1 / 2002$ \\
\hline California & $8 / 1 / 1997$ & $1 / 1 / 2000$ \\
\hline Colorado & $7 / 1 / 1987$ & $1 / 1 / 2000$ \\
\hline Connecticut & $7 / 1 / 1995$ & $7 / 1 / 2001$ \\
\hline Delaware & $10 / 1 / 1997$ & $1 / 1 / 2000$ \\
\hline Florida & $7 / 3 / 1986$ & $6 / 21 / 2001$ \\
\hline Georgia & $10 / 1 / 1993$ & $1 / 1 / 2003$ \\
\hline Hawaii & $3 / 31 / 1988$ & $7 / 1 / 2005$ \\
\hline Idaho & $4 / 14 / 1997$ & $7 / 1 / 2000$ \\
\hline Illinois & $7 / 1 / 1997$ & $7 / 1 / 2001$ \\
\hline Indiana & $7 / 1 / 1992$ & $8 / 22 / 2002$ \\
\hline Iowa & $7 / 1 / 1999$ & $1 / 1 / 2003$ \\
\hline Kansas & $7 / 1 / 1991$ & $4 / 5 / 2002$ \\
\hline Kentucky & $7 / 1 / 1993$ & $7 / 1 / 2000$ \\
\hline Louisiana & $7 / 15 / 19966^{38}$ & $1 / 1 / 2005$ \\
\hline Maine & $8 / 15 / 2001$ & $1 / 1 / 2002$ \\
\hline Maryland & $1 / 1 / 1997$ & $1 / 1 / 2003$ \\
\hline Massachusetts & $10 / 1 / 1994$ & $10 / 1 / 2002$ \\
\hline Michigan & $3 / 4 / 1999$ & $1 / 1 / 2006$ \\
\hline Minnesota & $4 / 1 / 2000$ & $9 / 1 / 2004$ \\
\hline Mississippi & $8 / 1 / 1986$ & $8 / 1 / 2001$ \\
\hline Missouri & $7 / 1 / 2006$ & $1 / 1 / 2013$ \\
\hline Montana & $8 / 28 / 1996$ & $8 / 28 / 2001$ \\
\hline Nebraska & $9 / 30 / 1989$ & $10 / 1 / 2003$ \\
\hline Nevada & $9 / 13 / 1997$ & $10 / 1 / 2003$ \\
\hline New Hampshire & $8 / 19 / 2006$ \\
\hline New Jersey & $4 / 17 / 1989$ & $1 / 1 / 2002$ \\
\hline New Mexico & $1 / 1 / 1999$ & \\
\hline & $6 / 5 / 1997$ & \\
\hline & $7 / 1 / 1995$ & \\
\hline
\end{tabular}

\footnotetext{
${ }^{37}$ Current through year-end 2014.

${ }^{38}$ This date was for institutional trustees only. Other trustees were permitted to opt into the reform effective $1 / 1 / 2005$.

${ }^{39}$ This date was for new trusts or existing trusts that opted for early application of the reform (otherwise the reform was effective for existing trusts on 1/1/2004).

${ }^{40}$ This date was for all institutional trustees and other trustees who opted in to the reform.
} 
Prudent Investor Rule

\begin{tabular}{lcc} 
New York & $1 / 1 / 1995^{41}$ & $1 / 1 / 2002$ \\
\hline North Carolina & $1 / 1 / 2000$ & $1 / 1 / 2004$ \\
\hline North Dakota & $8 / 1 / 1997$ & - \\
\hline Ohio & $3 / 22 / 1999$ & $1 / 1 / 2003$ \\
\hline Oklahoma & $11 / 1 / 1995$ & $11 / 1 / 1998$ \\
\hline Oregon & $9 / 9 / 1995$ & $1 / 1 / 2004$ \\
\hline Pennsylvania & $12 / 25 / 1999^{42}$ & $7 / 15 / 2002$ \\
\hline Rhode Island & $8 / 6 / 1996$ & $6 / 23 / 2006$ \\
\hline South Carolina & $6 / 5 / 1990$ & $7 / 18 / 2001$ \\
\hline South Dakota & $7 / 1 / 1995$ & $2 / 27 / 2002$ \\
\hline Tennessee & $7 / 1 / 1989$ & $7 / 1 / 2000$ \\
\hline Texas & $6 / 16 / 1991$ & $1 / 1 / 2004$ \\
\hline Utah & $7 / 1 / 1995$ & $5 / 3 / 2004$ \\
\hline Vermont & $7 / 1 / 1998$ & $7 / 1 / 2009$ \\
\hline Virginia & $7 / 1 / 1992$ & $1 / 1 / 2000$ \\
\hline Washington & $1 / 1 / 1985$ & $1 / 1 / 2003$ \\
\hline West Virginia & $7 / 1 / 1996$ & $7 / 1 / 2000$ \\
\hline Wisconsin & $4 / 30 / 2004$ & $5 / 17 / 2005$ \\
\hline Wyoming & $7 / 1 / 1999$ & $7 / 1 / 2001$
\end{tabular}

\footnotetext{
${ }^{41}$ This statute was based largely on the UPIA.

42 This statute was based largely on the UPIA.
} 